\title{
Origin and evolution of the Bezedna lake-mire complex in the Lublin area (East Poland): a case study for permafrost lakes in karstic regions
}

\author{
Radosław Dobrowolski $\cdot$ Piotr Kulesza • \\ Jacek Lojek • Irena Agnieszka Pidek
}

Received: 31 January 2013/Accepted: 7 November 2014/Published online: 11 December 2014

(C) The Author(s) 2014. This article is published with open access at Springerlink.com

\begin{abstract}
The Bezedna site represents a unique lakemire complex in the Lublin chalkland, eastern Poland. This karst region contains Upper Cretaceous carbonate rocks under the influence of continental climate. Using sedimentologic, palaeobotanical, and fossil ostracode analyses as well as radiocarbon dating on cores, we were able: (1) to reconstruct the morphogenetic mechanisms related to lake formation, (2) to describe the main stages of lake evolution, and (3) to identify the environmental conditions during this evolution. The first stage was the formation of an accumulation basin in a periglacial setting related to permafrost thawing in the last phase of the Weichselian and at the beginning of the Holocene. During the second stage, in the successive phases of the Holocene, lake evolution was determined by climate changes and local conditions, and in the youngest Subatlantic period-also by human activity in several settlement phases. Natural water
\end{abstract}

R. Dobrowolski $(\varangle) \cdot$ P. Kulesza $\cdot$ J. Łojek · I. A. Pidek Department of Geoecology and Paleogeography, Faculty of Earth Sciences and Spatial Management, Maria Curie-Skłodowska University, Kraśnicka 2 d, 20-718 Lublin, Poland

e-mail: radoslaw.dobrowolski@umcs.lublin.pl

P. Kulesza

e-mail: piotr.kulesza@poczta.umcs.lublin.pl

J. Łojek

e-mail: jaclojek@wp.pl

I. A. Pidek

e-mail: i.pidek@poczta.umcs.lublin.pl bodies in a karstic region create unique conditions for water circulation, especially for groundwater. During the change from the periglacial to temperate climate of the Holocene in the Lublin chalkland, the response of substratum (deeply frozen during the Weichselian) was influential in the development of surface water conditions in the study area. The strong fracturing of the Upper Cretaceous bedrock and general change of groundwater circulation associated with the activation of an ascending groundwater supply favored the intensive dissolution of carbonate and the progressive ground subsidence. Based on the reconstruction and correlation with paleoenvironmental investigations of the adjacent Volhynia chalkland, we were able to estimate and compare the influences of local (morphologic and geologic) conditions versus global climate changes on the paleoenvironmental record. Climatedriven lake-level fluctuations coincided over great areas of the Northern Hemisphere and are well reflected in changes of the Ostracoda fauna.

Keywords Multiproxy data $\cdot$ Paleoenvironmental changes · Late Weichselian · Holocene · Lublin chalkland

\section{Introduction}

The reconstruction of paleoenvironmental conditions based on the multi-proxy studies of lake and mire 
deposits are critical for understanding the variability of past climate changes. They are also a starting point for understanding modern environmental conditions as well as forecasting future changes. In special cases they also provide essential information about the processes forming lake basins. With karstic regions, such as the European chalklands, groundwater effects greatly influence the origin and morphogenetic evolution of a lake basin, especially during the last $13 \mathrm{ka}$ (Late Glacial and Holocene). The conditions of lake basin formation in areas with Pleistocene or/and modern permafrost occurrence are quite well understood and described (Müller 1959; Mackay 1978, 1988; Washburn 1979; Huijzer and Isarin 1997; Gurney 1998; Burn 2002; Wohlfarth et al. 2006; Kokfelt et al. 2010; O'Neill and Burn 2012; Karlsson et al. 2012). However, few papers deal with the morphogenetic processes resulting in the formation of lake basins in karstic regions affected by underground permafrost without suitable conditions for segregated ice formation (Dobrowolski 2006; Zwoliński et al. 2007). The main problem is the determination of the morphogenetic effects of thermokarst processes (connected with ground ice degradation) and strictly karst processes (connected with carbonate dissolution).

The Holocene environmental changes in Europe have a rich and varied multi-proxy record in which short-lived climate oscillations are recorded (Heiri et al. 2003; Magny et al. 2003; Kofler et al. 2005; Feurdean et al. 2007; Seppä et al. 2007; Belis et al. 2008). Their major driving factor was probably changing solar activity (Magny 2004). The timing and duration of major climatic shifts during the Late Glacial (especially Younger Dryas) and Holocene were similar in different regions of the world (Hoek and Bohncke 2002; Nakagawa et al. 2003), but minor climatic oscillations reveal the complexity of regional differences in paleoenvironment transformations driven by climatic changes (Björck et al. 1996; Litt and Stebich 1999; Litt et al. 2001; 2003). Many proxy records may not register even a hemispherically strong signal. In local conditions, a threshold that causes change is not crossed, and the response to large-scale climate shifts may therefore often seem diachronous (Koç et al. 1993; Coope and Lemdahl 1995). Barber et al. (2004) stressed that such differences in ecologic responses point to strong regional and local climatic gradients associated with these events, and they are not considered to a sufficient degree when inferring synchronicity of events among various records. So the determination of the intensity and directions of climatic changes at the supralocal level requires seeking new study sites with very long records of paleoecologic changes with multiple proxies.

The Lublin Chalkland of eastern Poland and western Ukraine is characterized by relief and hydrologic conditions determined by the lithology of the Upper Cretaceous carbonate bedrock. It is distinguished by the occurrence of numerous closed sinkholes, usually small and round, commonly filled by modern lake and/or mire ecosystems (Wilgat 1954; Maruszczak 1966). Sinkhole origin can be linked to either karstic or thermokarstic processes during the Late Glacial/Holocene transition (Wojtanowicz 1994). Multi-proxy investigations of biogenic deposits in karstic lake basins can elucidate their origin and the development conditions (Valero-Garces et al. 2014), including the Lublin chalkland (Harasimiuk et al. 2002; Dobrowolski 2006; Kulesza et al. 2011, 2012), and the neighboring area to the east, the Volhynia chalklands (Zernitskaya 1997; Dobrowolski 2006; Dobrowolski et al. 2001).

The aim of this study is to define the lake-mire basin origin for the Bezedna complex of the Lublin chalkland and to reconstruct its main evolution phases in the Late Glacial and Holocene using multiple proxies, including lithologic variation and microfossil distribution, from sediment cores.

\section{Study site}

The Bezedna site of eastern Poland $\left(51^{\circ} 06^{\prime} 08.6^{\prime \prime} \mathrm{N}\right.$, $23^{\circ} 30^{\prime} 22.4^{\prime \prime} \mathrm{E}$; area: 44 ha; altitude: $191.0 \mathrm{~m}$ a.s.1.) is the southernmost lake-mire complex of the Lublin chalkland (Fig. 1), situated on the geographic boundary between the East European Lowlands and NonAlpine Central Europe and located geologically along the edge of the East European craton. The complex includes the lake (6.5 ha in area; $1.5 \mathrm{~m}$ in depth; Table 1) and surrounding wetland belt ( $37.5 \mathrm{ha}$ ), composed mainly of reed and sedge mires. Its specific feature is the occurrence of a floating vegetation island in the middle of the lake (area 0.5 ha; thickness about $0.5 \mathrm{~m}$ ). The Upper Cretaceous chalkland or carbonate bedrock is composed of siliceous limestone containing sponge fossils and softer chalk deposits (Fig. 2a). The bedrock exhibits Cenozoic faults and joints (two systems: NW-SE/NE-SW and N-S/W, Dobrowolski 


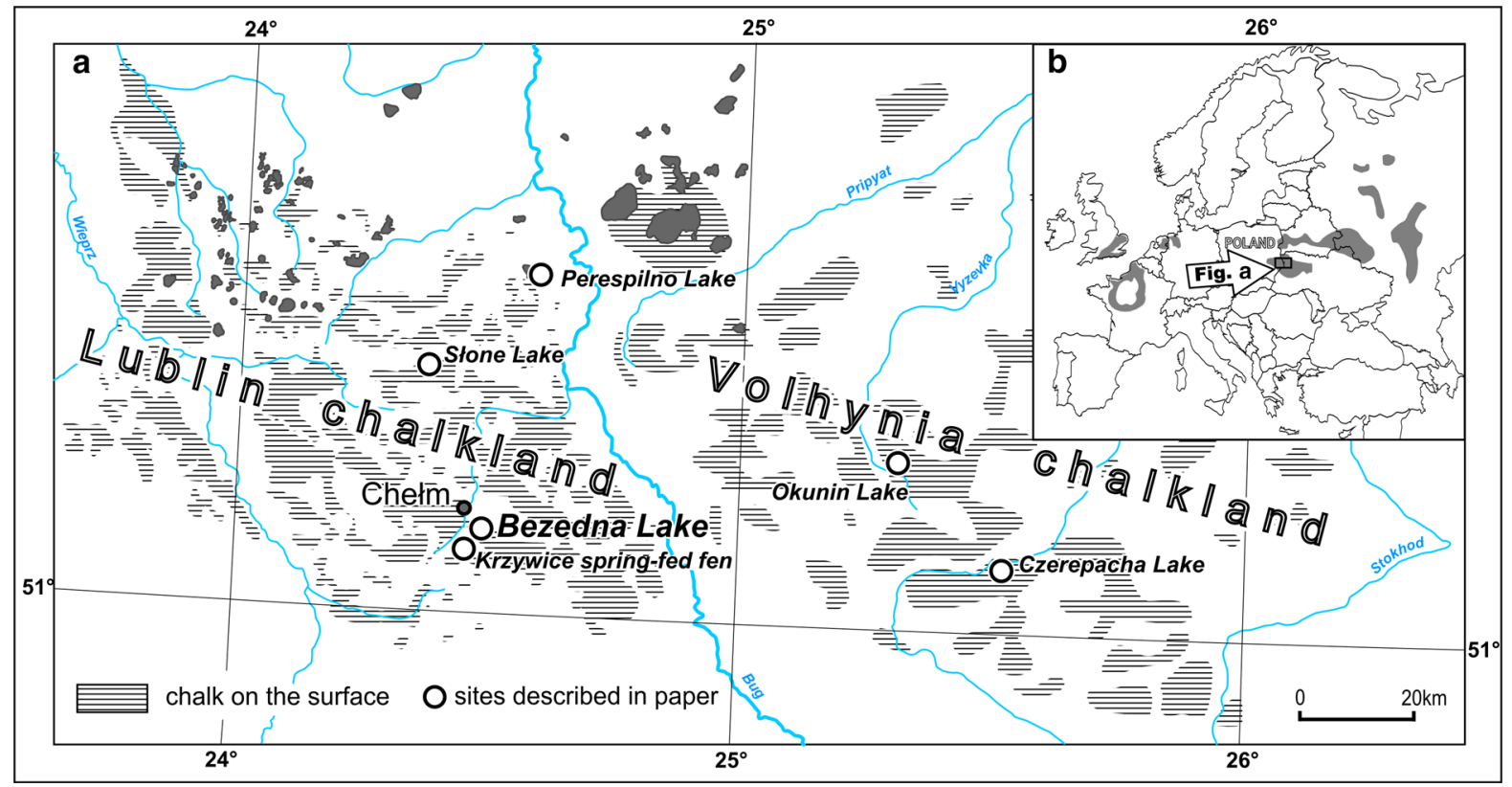

Fig. 1 a Location of Lake Bezedna and other sites described in the text in the Lublin and Volhynia chalklands of eastern Poland and western Ukraine and b general location of study area in relation to European chalklands' distribution (gray areas)

1995; Fig. 2b). The carbonate bedrock is covered only by thin $(<5 \mathrm{~m})$ patches of Saalian glacio-fluvial sands and glacial tills, which occur to the south of the site (Fig. 2a). Erosion-denudation relief with numerous closed depressions or sinkholes and small isolated hills are developed in the carbonate substratum in the site surroundings.

\section{Materials and methods}

\section{Chronology}

Radiocarbon dating was performed on samples of sediments with the highest content of OM. Due to the absence of macrofossils adequate for radiocarbon dating in the investigated cores across the mire-lake complex, bulk sediments were dated. Six samples of lacustrine deposits from core B16 from the middle of Lake Bezedna were dated using the ${ }^{14} \mathrm{C}$ AMS method. The samples were taken at the following depths: 3.45 , $7.90-7.95,8.10-8.15,8.80-8.85,9.60-9.65$, and 9.85-9.90 m. Dating was carried out in the Gliwice Radiocarbon Laboratory using the accelerator mass spectrometry technique. In this technique the $\mathrm{CO}_{2}$ obtained from the sample is converted to graphite that forms a target used to produce a beam of ionized carbon atoms, then accelerated to the energy of a few $\mathrm{MeV}$. In the magnetic field, the beam containing different carbon isotopes is split and the intensity of the ${ }^{14} \mathrm{C}$ beams of the unknown and standard samples are compared to determine the ${ }^{14} \mathrm{C}$ concentration. Radiocarbon dates were calibrated with OxCal v4.0.5 (Bronk Ramsey 2001) and the IntCal04 atmospheric curve (Reimer et al. 2004).

Sedimentology

Lithofacies identification of the organogenic and mineral sediments filling the lake-mire basin (Miall 1978) was performed based on 52 cores distributed regularly at the nodal points of $\mathrm{W}-\mathrm{E}$ and $\mathrm{N}-\mathrm{S}$ perpendicular transects across the lake-mire complex (Fig. 3a). The cores were drilled down to the limestone bedrock. This allowed for correlating the selected profiles for the purpose of detailed laboratory analysis. The core profiles taken in the terrestrial mire area (at 100-m intervals) and in the modern lake area (at 50-m intervals) contained the most complete and representative sedimentary sequence of the complex. All sediment cores with undisturbed structure (collected using a Russian corer) were described using: (1) 
Table 1 Physical parameters of Lake Bezedna

\begin{tabular}{|c|c|}
\hline & Bezedna lake \\
\hline Longitude & $23^{\circ} 30^{\prime} 22.4^{\prime \prime} \mathrm{E}$ \\
\hline Latitude & $51^{\circ} 06^{\prime} 08.6^{\prime \prime} \mathrm{N}$ \\
\hline Altitude (m a.s.1.) & 191.0 \\
\hline Average depth (m) & 1.0 \\
\hline Maximum depth (m) & 1.5 \\
\hline Maximum length (m) & 290 \\
\hline Maximum width (m) & 250 \\
\hline Area $\left(\mathrm{km}^{2}\right)$ & 0.065 \\
\hline Catchment area $\left(\mathrm{km}^{2}\right)$ & 0.44 \\
\hline Bedrock & $\begin{array}{l}\text { Chalk/limestone (Upper } \\
\text { Cretaceous) }\end{array}$ \\
\hline Quaternary deposits & $\begin{array}{l}\text { Saalian glaciofluvial } \\
\text { sands and glacial } \\
\text { tills (thickness }<5 \mathrm{~m} \text { ) }\end{array}$ \\
\hline Hydrochemical composition & July 2013 \\
\hline $\mathrm{pH}(\mu \mathrm{S} / \mathrm{cm})$ & 7.59 \\
\hline $\begin{array}{l}\text { Electrical conductivity } \\
{\left[25^{\circ} \mathrm{C}\right]\left(\mathrm{mval} \cdot \mathrm{dm}^{-3}\right)}\end{array}$ & 488 \\
\hline Alkalinity $\left(\mathrm{mg} \mathrm{dm}^{-3}\right)$ & 4.74 \\
\hline $\mathrm{HCO}_{3}{ }^{-}\left(\mathrm{mg} \mathrm{dm}^{-3}\right)$ & 289 \\
\hline $\mathrm{Cl}^{-}\left(\mathrm{mg} \mathrm{dm}^{-3}\right)$ & 7.5 \\
\hline $\mathrm{SO}_{4}{ }^{2-}\left(\mathrm{mg} \mathrm{dm}^{-3}\right)$ & 10.1 \\
\hline $\mathrm{Ca}^{2+}\left(\mathrm{mg} \mathrm{dm}^{-3}\right)$ & 94.3 \\
\hline $\mathrm{Mg}^{2+}\left(\mathrm{mg} \mathrm{dm}^{-3}\right)$ & 3.5 \\
\hline $\mathrm{Na}^{+}\left(\mathrm{mg} \mathrm{dm}^{-3}\right)$ & 3.5 \\
\hline $\mathrm{K}^{+}\left(\mathrm{mg} \mathrm{dm}^{-3}\right)$ & 6.9 \\
\hline $\mathrm{Sr}^{2+}\left(\mathrm{mg} \mathrm{dm}^{-3}\right)$ & 0.7 \\
\hline $\mathrm{NH}_{4}^{+}\left(\mathrm{mg} \mathrm{dm}^{-3}\right)$ & 0.23 \\
\hline $\mathrm{Li}^{+}\left(\mathrm{mg} \mathrm{dm}^{-3}\right)$ & 0.01 \\
\hline $\mathrm{NO}_{2}^{-}\left(\mathrm{mg} \mathrm{dm}^{-3}\right)$ & $<0.01$ \\
\hline $\mathrm{NO}_{3}^{-}\left(\mathrm{mg} \mathrm{dm}^{-3}\right)$ & 0.04 \\
\hline $\mathrm{F}^{-}\left(\mathrm{mg} \mathrm{dm}^{-3}\right)$ & 0.13 \\
\hline $\mathrm{N}_{\text {tot }}\left(\mathrm{mg} \mathrm{dm}^{-3}\right)$ & 1.24 \\
\hline$P_{\text {tot }}\left(\mathrm{mg} \mathrm{dm}^{-3}\right)$ & 0.03 \\
\hline TOC $\left(\mathrm{mg} \mathrm{dm}^{-3}\right)$ & 19.9 \\
\hline TDS $(\mu \mathrm{S} / \mathrm{cm})$ & 416 \\
\hline
\end{tabular}

lithologic description following the Schnurrenberger et al. (2003) classification of lacustrine sediments, (2) lithofacies code for sedimentary rocks (Miall 1978), and (3) Troels-Smith formula for the description of the organogenic deposits (Troels-Smith 1955). The core denoted as no. 16 (Fig. 3) or B16 (Figs. 4, 5), 9.95 m long, taken from the central part of the lake, was
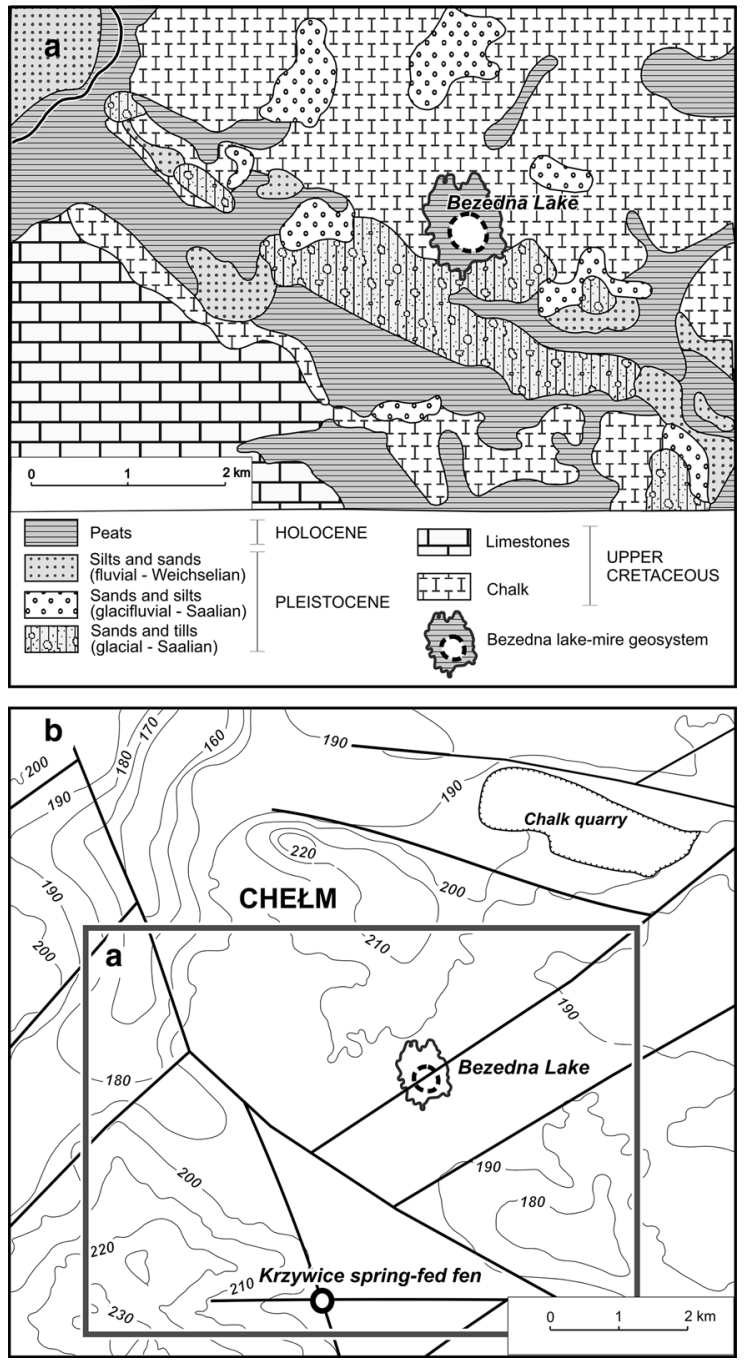

Fig. 2 a Geologic sketch map of the study area (after Harasimiuk et al. 2006a, b) with generalized stratigraphy. The karst bedrock is composed of Upper Cretaceous siliceous limestone with sponge fossils and softer chalk deposits. b Tectonic features against a background of the sub-Quaternary topographic relief; black lines depict main mesofaults in the chalk/limestone landscape

subjected to palynologic and fossil ostracode analyses as well as radiocarbon dating.

\section{Pollen stratigraphy}

Samples for palynologic analysis $\left(1 \mathrm{~cm}^{3}\right.$ of sediment) were taken at every $5-\mathrm{cm}$ interval in core B16 at the center of modern Lake Bezedna. In total 95 pollen samples were analyzed at intervals every $5-20 \mathrm{~cm}$, 

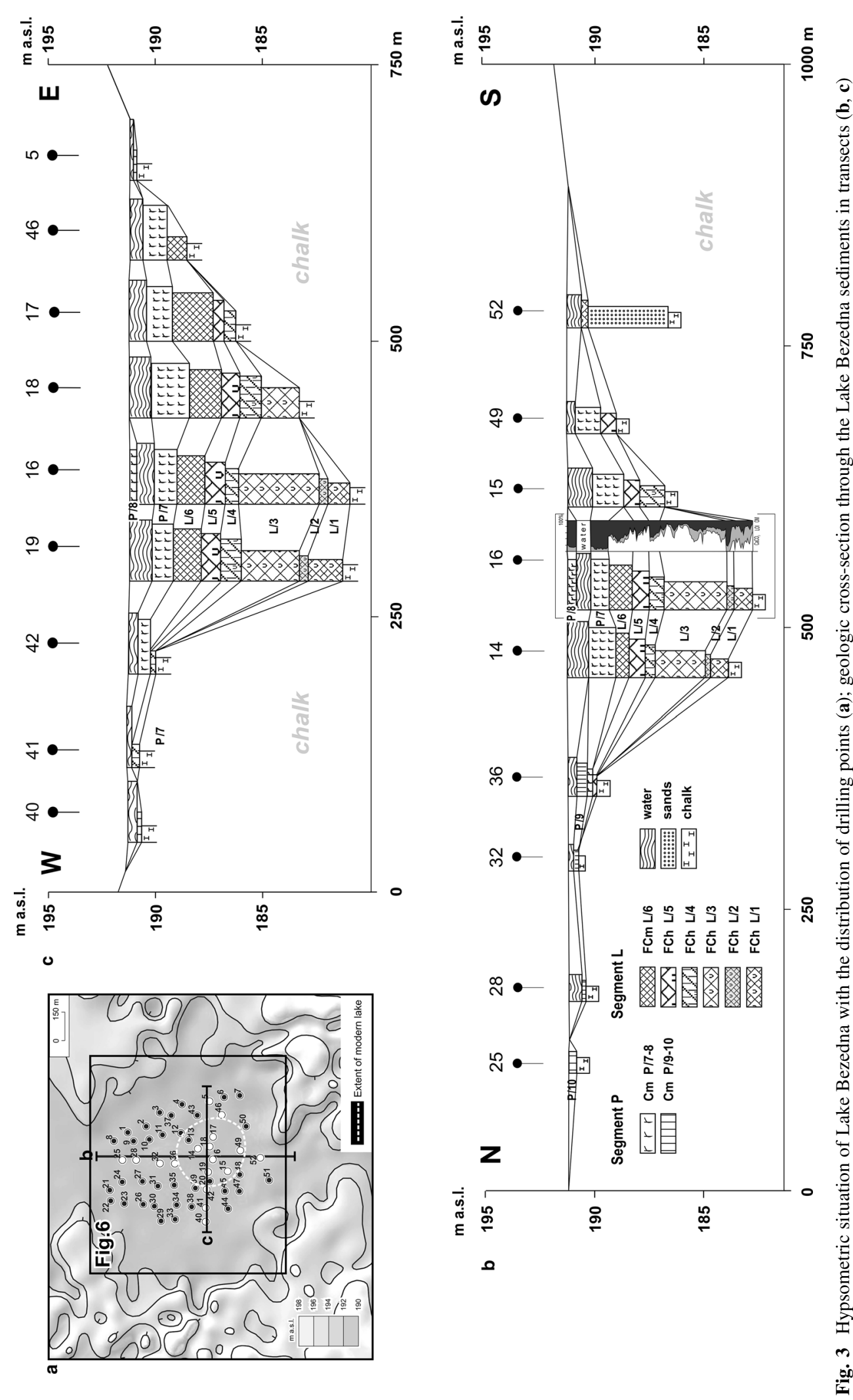


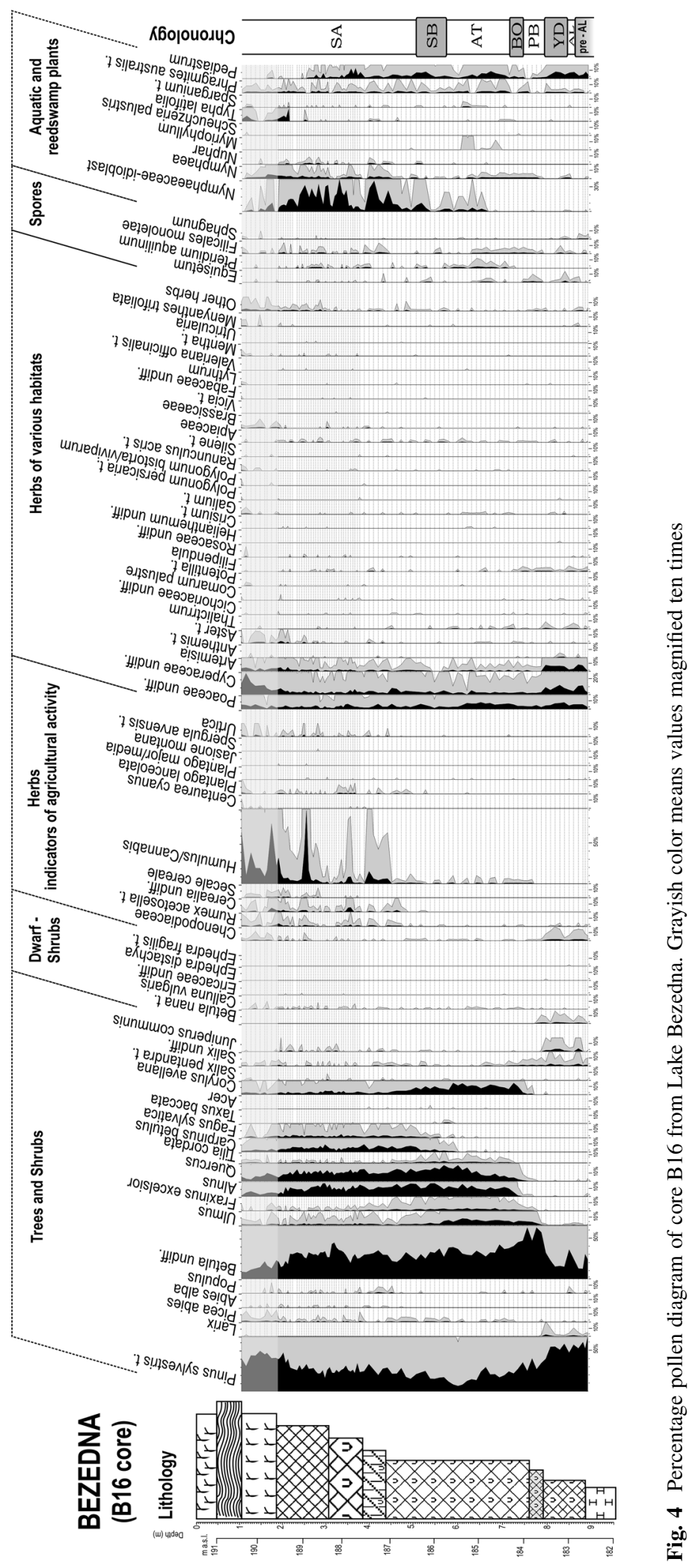




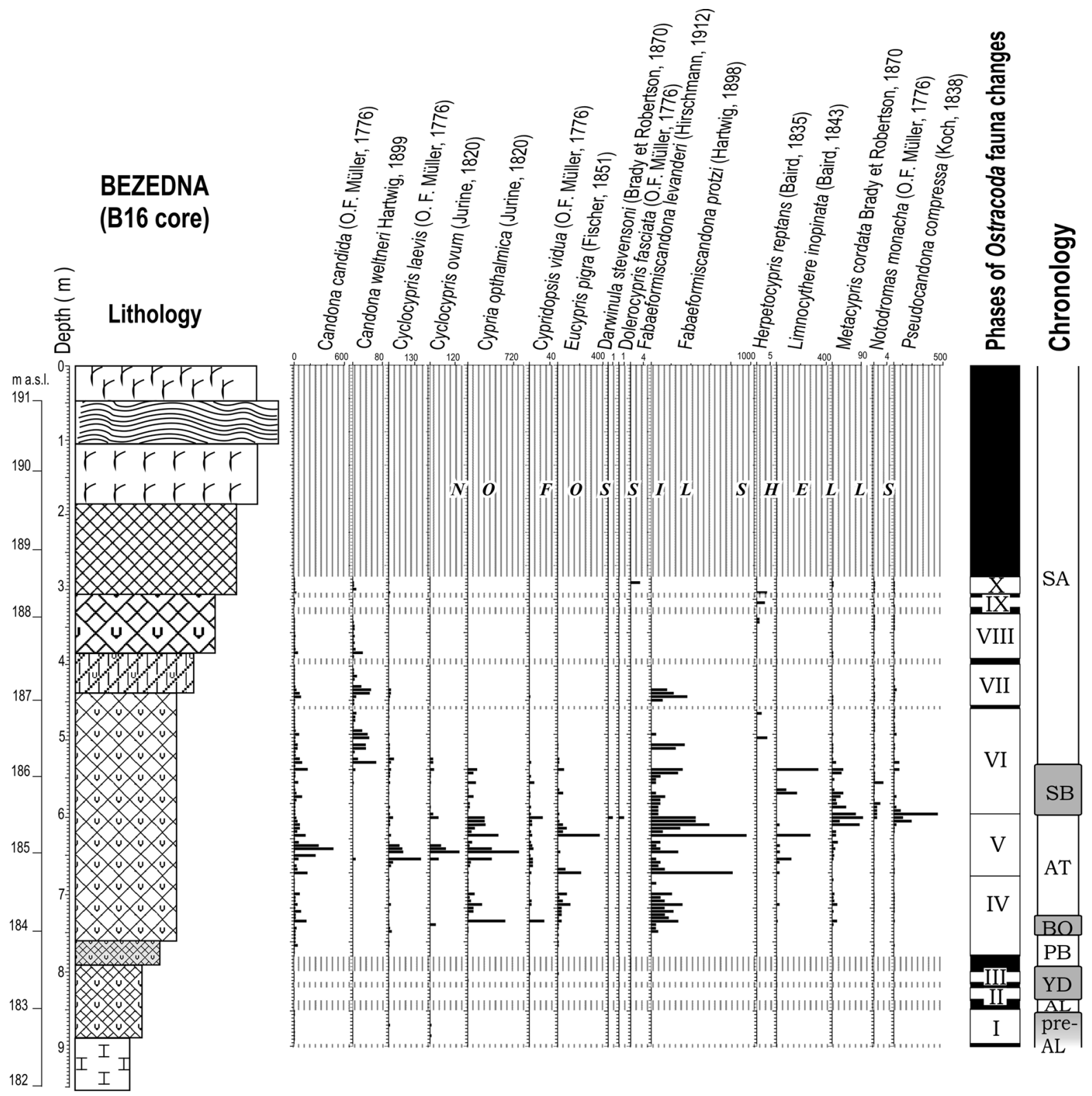

Fig. 5 Distribution and frequencies of ostracodes in core B16 from Lake Bezedna

depending on changes in sediment composition. The samples were macerated using the standard method of Erdtman's acetolysis, after carbonates were removed by means of 10 percent $\mathrm{HCl}$, and the mineral fraction by means of 40 percent HF (Berglund and RalskaJasiewiczowa 1986). Pollen spectra were always counted on at least two microscopic slides. The basic sum used for percentage calculations is the sum of tree and shrub pollen (arboreal pollen-AP) and of herb pollen (non-arboreal pollen-NAP), excluding the pollen of aquatic and reed-swamp plants, Pteridophyta and Bryophyta spores, as well as Pediastrum Meyen algae. The results of the palynologic analysis are presented on a pollen diagram (Fig. 4) prepared using POLPAL software (Nalepka and Walanus 2003). 


\section{Ostracodes}

For the fossil Ostracoda analysis, 140 sediment samples with a volume of $5 \mathrm{~cm}^{3}$ each were collected from across the no. 16 core from the middle of Lake Bezedna from $10.0 \mathrm{~m}$ through $3.0 \mathrm{~m}$ depth. Sediment was washed through a $0.25-\mathrm{mm}$-mesh sieve. The dried residue was analyzed under the microscope. Species assignment was performed based on the shape, size, and the sculpture features of valves and carapaces (Meisch 2000). The results of the Ostracoda analysis are presented on a diagram plotted using Pangea PanPlot (Diepenbroek et al. 2001) (Fig. 5).

\section{Results}

\section{Sedimentology}

Organogenic deposits in the Bezedna site consist of two genetically different segments: limnic (coded L) and paludal (coded P). Segment L includes six units (Table 2; Figs. 3, 6). The bottom unit (coded L/1) is very finely laminated, sapropelic carbonate mud (light gray to grayish brown), with relatively small variability in $\mathrm{OM}$ content (from 15 to $34 \%$ ) and high variability in $\mathrm{CaCO}_{3}$ content (from $18 \%$ to $62 \%$ ). The average value of LOI is $78 \%$. Thickness of individual laminae in this unit varies from 1 to $2 \mathrm{~mm}$. The lithofacies association L/1 passes upwards gradually into unit $\mathrm{L} / 2$, which is composed of massive, dark brown sapropel (average content of OM is $66 \%$, and LOI $30 \%$ ) with a small amount of dispersed micritic calcite grains (average content of $\mathrm{CaCO}_{3}$ is $<5 \%$ ). Thickness of $\mathrm{L} / 2$ is approximately $20-30 \mathrm{~cm}$. Similar to unit L/1, it occurs only in a narrow zone, which is elongated in the NE-SW direction (Fig. 6), i.e. along the Cenozoic mesofault (Fig. 2b; after Harasimiuk et al. 2006a, b). Unit L/3 is $2-3.5$ m thick and contains thickly laminated (individual laminae are 5-10 mm thick), sapropelic carbonate mud with carbonate skeletal clasts of mollusk shells. The OM content ranges from 11 to $41 \%, \mathrm{CaCO}_{3}$ from 28 to $85 \%$, and LOI from 69 to $88 \%$. Lateral extent of unit $\mathrm{L} / 3$ is considerably greater than that of the underlying units; its area is about 14 ha and it is almost six times larger than the areas covered by units $\mathrm{L} / 1$ and $\mathrm{L} / 2$. Unit L/4 (with a thickness of $0.5-0.8 \mathrm{~m}$ ) occurs only within the main lake basin and several adjacent, shallow and closed sedimentation basins. It is composed of dark gray, thickly laminated sapropel with the average OM content of $46 \%$. Dispersed micritic calcite grains (average content of $\mathrm{CaCO}_{3}$ is $42 \%$ ) are common. Unit L/4 passes upwards gradually into the thinly laminated, sapropelic carbonate mud of unit L/5 with a thickness of about $1 \mathrm{~m}$. Content of OM ranges from 20 to $43 \%, \mathrm{CaCO}_{3}$ from 50 to $75 \%$, and LOI from 48 to $76 \%$. Unit L/5 occurs in the main basin and also in the shallower paleodepressions forming the Bezedna lake-mire complex (Fig. 6). The top part of this limnic segment is composed of brownish gray, massive sapropel (OM 40-60\%; LOI 41-76\%) with dispersed micritic calcite grains and macrofossils (Phragmites Adanson). Total thickness of the limnic segment (units L/1-6) changes from $0.5 \mathrm{~m}$ at the margins of the studied lake-mire complex to $7 \mathrm{~m}$ in the northwestern part of the modern lake. Lateral extent of this segment indicates that in the past the lake was two times larger than it is at present.

The paludal segment $(\mathrm{P})$ overlies the limnic segment $\mathrm{L}$ in the central part of the site and it also occurs in the margins of the complex. It thickness ranges from about $1.5 \mathrm{~m}$ in the central part of the complex to $<0.5 \mathrm{~m}$ at its margins (Fig. 6). This paludal segment includes four units $(\mathrm{P} / 7-\mathrm{P} / 10)$. Two of them (P/9 and P/10; Table 3, Figs. 3, 6) occur independently of the limnic segment $\mathrm{L}$ at the margins and two other (P/7 and P/8; Table 3; Figs. 3, 6) overlie segment L. The units $\mathrm{P} / 7$ and $\mathrm{P} / 8$ (Table 2) are represented by non-carbonate blackish brown, massive, moist, slightly to somewhat decomposed reed and reed-sedge peats (80-87 \% OM), with numerous macrofossils (Phragmites). P/9 unit is composed of grayish black, massive humic silty clay with content of organic matter about $20 \%$. The $\mathrm{P} / 10$ unit has a quite different composition (Table 3), which can be described as non-carbonate blackish-brown, massive, highly decomposed herbaceous sedge peat (75\% OM) with one type of macrofossil (Carex L.).

\section{Pollen stratigraphy}

The pollen diagram in Fig. 4 records the history of vegetation surrounding the Bezedna complex since the Late Glacial of the last glaciation. Palynostratigraphic division of the pollen diagram was based on the distinctive events in vegetation cover development (Latałowa 2003), which occurred in individual periods 
Table 2 Lithologic description of the Lake Bezedna limnetic (L) sediments (core B16, location shown in Fig. 3)

\begin{tabular}{lllll}
\hline $\begin{array}{l}\text { Depth } \\
(\mathrm{m})\end{array}$ & $\begin{array}{l}\text { Segment/ } \\
\text { unit }\end{array}$ & $\begin{array}{l}\text { Lithologic description } \\
\text { (after Schnurrenberger et al. 2003) }\end{array}$ & $\begin{array}{l}\text { Lithofacies } \\
\text { code (after } \\
\text { Miall 1978) }\end{array}$ & $\begin{array}{l}\text { T-S formula } \\
\text { (after Troels-Smith 1955) }\end{array}$ \\
\hline $0.0-0.40$ & $\mathrm{P} / 8$ & $\begin{array}{l}\text { Blackish brown, massive, moist, slightly decomposed } \\
\text { herbaceous reed peat }(80 \% \mathrm{OM}), \text { with numerous } \\
\text { macrofossils (Phragmites) } ; \mathrm{CaCO}_{3} 0 \%\end{array}$ & $\mathrm{Cm}$ & $\begin{array}{c}\mathrm{Th}^{0} 4, \mathrm{Dh}++, \text { nig.3, strf. 0, } \\
\text { elas. 3, sicc. } 2\end{array}$
\end{tabular}

0.40-1.10 Water

1.10-1.95 P/7 Blackish brown, massive, moist, somewhat decomposed $\mathrm{Cm}$ herbaceous reed-sedge peat ( $87 \%$ OM), with numerous macrofossils (Phragmites), indistinct contact with underlying bed; $\mathrm{CaCO}_{3}(0 \%)$

1.95-3.05 L/6

Brownish gray, massive, moist, sapropel (OM $49 \%$ ), with dispersed amorphous micritic calcite. Indistinct contact with underlying bed, one macrofossil (Phragmites); $\mathrm{CaCO}_{3}(40 \%)$

Light gray to dark gray, thinly laminated (2-5 mm thick) with laminae of calcite and highly decomposed plant and animal remains. Moist, sapropelic (OM $31 \%$ ) carbonate $(65 \%)$ mud with carbonate skeletal elements of mollusks, diffuse contact with underlying bed

$3.85-4.40 \quad \mathrm{~L} / 4$

Dark gray, thickly laminated (5-20 mm thick) with laminae of calcite and highly decomposed plant and animal remains. Sapropel (OM $46 \%$ ) with dispersed amorphous micritic calcite, numerous carbonate skeletal elements of mollusks, diffuse contact with underlying bed; $\mathrm{CaCO}_{3}(42 \%)$

Light gray to dark gray, thickly laminated $(5-10 \mathrm{~mm}$ thick) with laminae of calcite and highly decomposed plant and animal remains. Moist, sapropelic (OM $20 \%)$ carbonate $(60 \%)$ mud with carbonate skeletal elements of mollusks, indistinct contact with underlying bed

$7.55-7.80 \quad \mathrm{~L} / 2$

Dark brown to brownish black, massive, moist, sapropel $\mathrm{FCm}$ (OM $66 \%)$; indistinct contact with underlying bed; $\mathrm{CaCO}_{3}(0 \%)$

7.80-8.78 L/1 Light gray to grayish brown, very finely laminated (1-2 mm thick) with calcite and clay laminae. Moist, sapropelic (OM $26 \%$ ) carbonate $(45 \%)$ mud, diffuse contact with underlying bed

8.78-9.00 Bedrock Light gray, massive, calcium carbonate $(65 \%)$ with silty Fm clay

FCh

FCh

FCh

Fm
$\mathrm{Th}^{1} 4, \mathrm{Dh}+$, nig. 3 , strf. 0 , elas. 3, sicc. 2, lim. 0 .

Ld3, Lc1, Dh+, part. test. (moll), nig.3, strf. 0, elas. 2, sicc. 2, lim. 0.

Lc3, Ld1, part. test. (moll), nig. 1 , strf. 1 , elas. 2 , sicc. 3 , lim. 1 .

Ld2, Lc2, part. test (moll), nig.2, strf. 1 , elas. 2 , sicc. 3 , lim. 1 .

Lc3, Ld1, test. part (moll), nig. 2 , strf. 1 , elas. 2 , sicc. 3 , lim. 0 .

Ld4, nig.4, strf. 0, elas. 3, sicc. 3 , lim. 0 .

Lc3, Ld1, nig.2, strf. 2, elas. 2, sicc. 3 , lim. 1 .

As3, Ag1, nig.1, strf. 0, elas. 0, sicc. 3, lim. 1 . both in the Late Glacial and the Holocene. In the Late Glacial part of the cores (L/1 unit), the following characters were noted in three units: (1) predominance of Cyperaceae, Poaceae, Artemisia L., Chenopodiaceae, and high pollen values of Salix L. undiff. and Juniperus L.; (2) increase in the pollen values of birch and pine; and (3) continued high pollen values of Artemisia, Poaceae and Cyperaceae, Salix undiff. Juniperus and the occurrence of Ephedra distachya L. and E. fragilis Desf. These units represent the pre-
Allerød period (1), Allerød warming (2), and Younger Dryas (3).

The end of the Late Glacial and the beginning of the Preboreal is well defined in the sediments (bottom part of the L/2 unit) and pollen diagram as well. Pollen values of Betula L. reach $70 \%$, and the percentages of NAP, Salix undiff., and Juniperus communis L. decreased reflecting the replacement of the communities with Artemisia and other heliophytes by birch forests with pine as the second important component. 
Fig. 6 Isopleth maps of the extents of lithostratigraphic units in the limnic (L) and paludic $(\mathrm{P})$ segments based on the cores' descriptions (see text for details); drilling points marked with numbers

\section{Segment L}

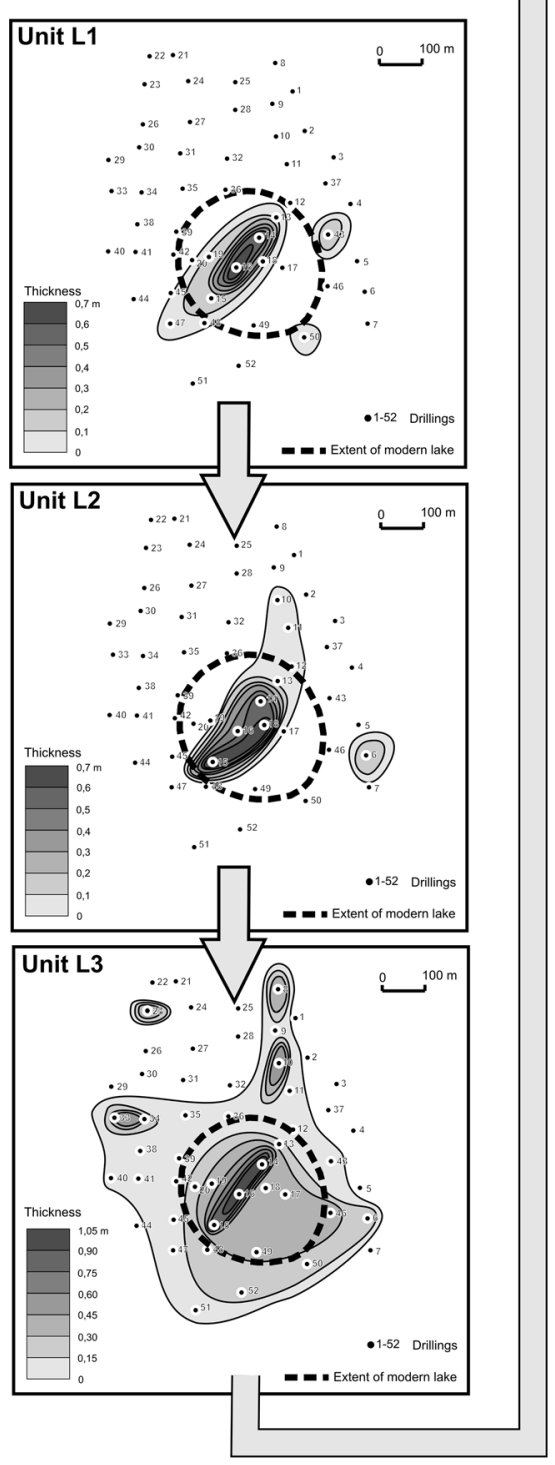

Segment $P$

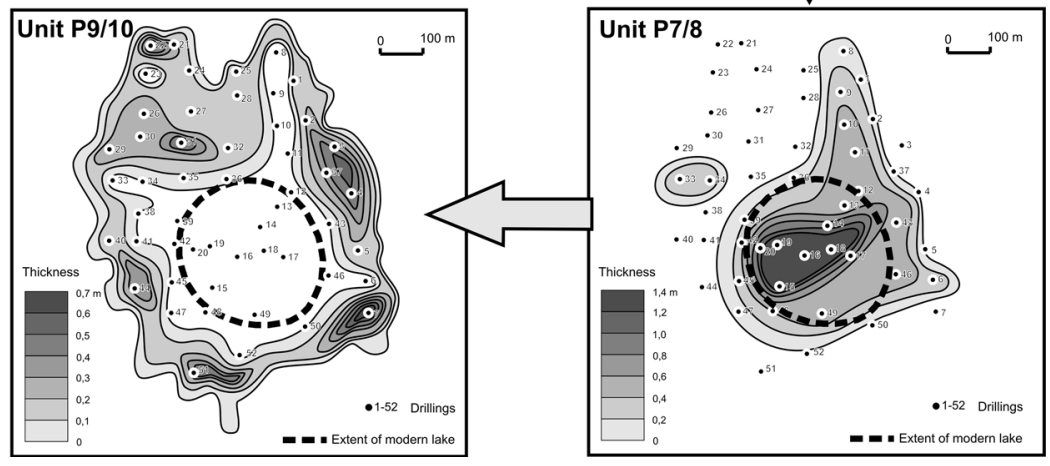


Table 3 Lithologic description of Lake Bezedna paludal (P) sediments overlying limnetic sediments (L) (core B40; location shown in Fig. 3)

\begin{tabular}{|c|c|c|c|c|}
\hline $\begin{array}{l}\text { Depth } \\
(\mathrm{m})\end{array}$ & $\begin{array}{l}\text { Segment/ } \\
\text { unit }\end{array}$ & $\begin{array}{l}\text { Lithologic description (after } \\
\text { Schnurrenberger et al. 2003) }\end{array}$ & $\begin{array}{l}\text { Lithofacies } \\
\text { code (after } \\
\text { Miall 1978) }\end{array}$ & $\begin{array}{l}\text { T-S formula (after } \\
\text { Troels-Smith } \\
\text { 1955) }\end{array}$ \\
\hline $0.0-0.60$ & $\mathrm{P} / 10$ & $\begin{array}{l}\text { Blackish brown, massive, highly } \\
\text { decomposed herbaceous sedge } \\
\text { peat ( } 75 \% \mathrm{OM}) \text {, with single } \\
\text { macrofossils (Carex); } \mathrm{CaCO}_{3} 0 \%\end{array}$ & $\mathrm{Cm}$ & $\begin{array}{l}\mathrm{Th}^{0} 4, \mathrm{Dh}++, \\
\text { nig. } 3 \text {, strf. } 0, \\
\text { elas. } 2 \text {, sicc. } 2\end{array}$ \\
\hline $0.60-0.80$ & $\mathrm{P} / 9$ & $\begin{array}{l}\text { Grayish black, massive humic silty } \\
\text { clay (OM } 20 \% \text { ), diffuse contact } \\
\text { with underlying bed }\end{array}$ & $\mathrm{Fm}$ & $\begin{array}{l}\text { As2, } \operatorname{Ag} 1, \operatorname{Dg} 1, \\
\text { nig. } 2, \text { strf. } 0, \\
\text { elas. } 0, \text { sicc. } 2, \\
\text { lim. } 1 .\end{array}$ \\
\hline $0.80-1.00$ & Bedrock & $\begin{array}{l}\text { Light gray, massive, calcium } \\
\text { carbonate }(71 \%) \text { with silty clay }\end{array}$ & $\mathrm{Fm}$ & $\begin{array}{l}\mathrm{Ag} 4, \text { As }++, \\
\text { nig. } 1, \text { strf. } 0, \\
\text { elas. } 0, \text { sicc. } 2 \text {, } \\
\text { lim. } 0 .\end{array}$ \\
\hline
\end{tabular}

At first larch was also present but soon it was replaced by trees with greater temperature requirements. Continuous occurrence of Ulmus is noteworthy and its percentages quickly rise to $4 \%$. Humulus lupulus L. pollen appears at the same time. Soon after the rise of Ulmus L., the quickly rising pollen values of Corylus L. and low percentages of Fraxinus L., which was the second component of riverine forests, appear. At present Fraxinus forms ash or elm-ash riverine forests, occupying habitats on the substratum rich in calcium carbonate in stream valleys and also in wet depressions. High pollen values of Corylus reflect intensive development of hazel in the understorey, which lasted throughout the Boreal period (bottom part of the L/3 unit). Subsequent increase in Quercus L. and Ulmus percentages with simultaneous drop of Pinus L. and appearance of Tilia Mill. show the replacement of pine communities by oak, elm, and a new-comer, lime. In the Atlantic period (middle part of the L/3 unit), thermophilous trees (Ulmus, Quercus, Fraxinus, Tilia) dominated the forests. At the beginning the forests were open so the understorey with heliophilous hazel could have developed. It is indicated by a consistently high Corylus proportion in the pollen diagram in the older part of the Atlantic period (Fig. 4). Percentage of NAP in pollen diagram decreases to a minimum indicating that open areas were very limited at that time. Bracken started to appear regularly in the herb layer. Increase in the pollen percentages of Alnus Mill. with simultaneous decrease of Cyperaceae and Salix reflect alder encroachment on wet and waterlogged habitats. Sedges and willows, till then quite abundant in the Lake Bezedna surroundings, were probably replaced by expanding alder. It was represented probably by Alnus glutinosa (L.) Gaertn., whose maximum expansion was recorded in the Atlantic period. The pollen spectra representing the second part of this period contain also Picea abies (L.) Karsten, Fagus sylvatica L. and Carpinus betulus L., which started to appear more regularly. These episodes indicate that hornbeam and beech moved from their glacial refugia, and the extent of spruce was shifted.

The beginning of the Subboreal period (upper part of the $L / 3$ unit) is marked in the pollen diagram by a decrease of elm proportion followed by a slight decrease of ash percentages and the continuous appearance of hornbeam and beech. The values of two latter taxa quickly increased. Simultaneously an increase in Quercus and Corylus proportions is visible, too.

The thickest part of lacustrine deposits (L/4-L/6 units) and peat deposits (P/7-P/8) represents the Subatlantic period when distinct expansion of Carpinus betulus and Fagus sylvatica occurred. It is reflected by a considerable proportion of their pollen. Several phases of human activity were recorded in the natural environment at that time by increasing percentages of herb pollen with indicators of pasturage and farming. Since then human impact has been determining the composition of vegetation cover. Almost continuous occurrence of Cerealia undiff. pollen, with several distinct increases, is noticeable in 
the pollen diagram of the Subatlantic period (L/4-L/6 units) and peat deposits (P/7-P/8) indicating cereal cultivation, and from a depth of $4.70 \mathrm{~m}$ pollen of Secale cereale $\mathrm{L}$. is permanently present $(\mathrm{L} / 5-\mathrm{L} / 6$ units). At the same time the pollen values of pasturage indicators increase considerably and several maxima of Humulus L./Cannabis L. pollen occur (L/5-L/6 units). The uppermost part of the pollen diagram (Fig. 4, shadow area) exhibits features of disturbances in pollen spectra and cannot be interpreted in terms of human impact changes ( $\mathrm{P} / 7$ unit).

\section{Ostracodes}

The identification of species for the ostracode fossil shells revealed sixteen ostracode species. Their frequency in the individual layers of deposits was variable, which was related to the changes in paleoenvironmental conditions. Based on the changing number of fossil shells in the individual layers, ten phases of fauna development were distinguished (Fig. 5). Fossils were absent in seven layers of different thicknesses. The first three phases (depth of 10.00-8.65 m-unit L/1, L/2 and bottom part of L/3) were characterized by low total number of shells (maximum of 22 fossil shells in $5 \mathrm{~cm}^{3}$ of deposit), and the most abundant were Candona candida (O.F. Müller 1776) and Fabaeformiscandona protzi (Hartwig 1898). Fabaeformiscandona protzi is known from cold reservoirs in both littoral and profundal zones and considered to be a cold-stenothermal and oligotrophic species (Meisch 2000) and a winter form (Hiller 1972).

Ostracode phase I (unit L/1) coincided with the preAllerød period according to the pollen stratigraphy. Besides a low total number of shells, it was characterized by a high variability of shells of individual species. Three layers without fossils were found within the depth range of $9.40-8.65 \mathrm{~cm}$ (unit L/2 and bottom part of L/3). The layers without fauna were separated by ostracode phases II and III, which are represented by the deposits containing only two species (Candona candida and Fabaeformiscandona protzi) in very small numbers. Ostracode phases II and III coincided with the Allerød and Younger Dryas, respectively.

Ostracode phase IV (unit L/3) covered the Preboreal, Boreal, and beginning of the Atlantic and was characterized by a considerably higher amount of ostracode species and specimens (up to seven species and 105 shells in $5 \mathrm{~cm}^{3}$ of deposit). Candona candida and Fabaeformiscandona protzi were predominant again, while Darwinula stevensoni Brady and Robertson 1870 and Metacypris cordata Brady and Robertson 1870 appeared. Darwinula stevensoni lives all year round at the bottom of freshwater bodies with the water depth of at least $2 \mathrm{~m}$ with a preference for depths $<6 \mathrm{~m}$ (Wilkinson et al. 2005). Metacypris cordata prefers eutrophic environments and its presence is indicative of the aging of a lacustrine waterbody, linked to the formation of peaty humic waters (Griffiths and Evans 1995). Toward the end of ostracode phase IV, the number of species and specimens gradually decreased. The fauna communities were only composed of Candona candida, Darwinula stewensoni and Fabaeformiscandona protzi.

Ostracode phase $\mathrm{V}$ (unit L/3) was a period of ostracode revival in terms of species diversity and number of specimens. From among eleven species, the most abundant were Candona candida, Fabaeformiscandona protzi, and Darwinula stevensoni. The conditions for water fauna development stabilized in the second part of ostracode phase $\mathrm{V}$, which coincided with the middle of the Atlantic time. The number of species and specimens were reduced in the successive layers. Fabaeformiscandona protzi, Pseudocandona compressa (Koch 1838), Candona candida, and Cypria ophtalmica (Jurine 1820) dominated in these communities. Dolerocypris fasciata (O.F. Müller 1776) and Notodromas monacha (O.F. Müller 1776) also occurred. Dolerocypris fasciata and Notodromas monacha are characteristic for permanent, quiet waters with a muddy bottom and rich vegetation, generally present in the littoral zone of lakes. This assemblage is indicative of a warm lake with dense vegetation.

The beginning of ostracode phase VI (unit L/3) coincided with the beginning of the Subboreal and was characterized by stable conditions with a relatively high number of specimens and high species diversity. Towards the end of this ostracode phase, the number of species and specimens gradually decreased. The appearance of Candona weltneri Hartwig, 1899 is a distinctive feature of the ostracode phase VI. In the second part of the ostracode phase VI, correlated with the beginning of the Subatlantic, the number of species and specimens considerably decreased. The ostracode 
communities consisted of Candona candida, Pseudocandona compressa, and Cyclocypris laevis (O. F. Müller 1776). Temperature increase and water level lowering are indicated from this ostracode assemblage: profundal species were replaced by littoral ostracode taxa (Limnocythere inopinata, Pseudocandona compressa). The species and specimen impoverishment was continuous and resulted in the complete disappearance of the fauna within the depth range of $5.05-5.00 \mathrm{~m}$ in sapropelic carbonate mud of unit $\mathrm{L} / 3$.

In ostracode phase VII, faunal composition was in general the same as in the previous phase but the number of specimens considerably increased (dark gray, thickly laminated sapropel of Unit L/4). Candona candida, Fabaeformiscandona protzi, and Candona weltneri were especially abundant. The second part of ostracode phase VII was characterized by a generally low but very fluctuating number of specimens. The communities were formed by only three species: Candona candida, Fabaeformiscandona protzi, and Candona weltneri. The next stage of ostracode disappearance occurred toward the end of ostracode phase VII (on the depth of 4.40-4.30 m unit L/4 passes upwards gradually into the thinly laminated, sapropelic carbonate mud of unit L/5).

The species within the communities at the beginning of ostracode phase VIII were similar to the previous ostracode phase.. The number of specimens was still rather low, and the most abundant were Candona candida and Candona weltneri. In the second part of the phase VIII, Pseudocandona compressa re-appeared and Herpetocypris reptans (Baird 1835) was found but the number of specimens was low. Herpetocypris reptans prefers shallow water conditions (Meisch 2000) and lives in water bodies with a muddy bottom and rich vegetation, preferably with high water energy (Griffiths 1995). Ostracodes are absent at depth interval 3.65-3.55 m (transition from unit $\mathrm{L} / 5$ to $\mathrm{L} / 6$ ).

Ostracode phase IX was also characterized by low number of specimens and frequent changes of species composition. The following species appeared for a short time: Cyclocypris laevis, Metacypris cordata, Pseudocandona compressa and Herpetocypris reptans. The deposits from a depth of 3.40-3.35 m are characterized by lack of fossil shells (bottom part of unit L/6. A relatively high number of species (6) and specimens (about 60) was found above in the deposits (unit L6) representing the beginning of the phase X. The communities were composed, among others, by the following species, which occurred also in the previous phases: Candona candida, Metacypris cordata, Candona weltneri and Pseudocandona compressa. The second part of the phase $\mathrm{X}$ was the last time when Ostracoda occurred in the lake. They are represented by single shells of only two speciesCandona candida and Pseudocandona compressa (lower part of unit L/6).

\section{Chronology}

The results of radiocarbon dating of the Bezedna lakemire profile are presented in Table 4 . The dating result obtained for sediments representing the bottom part of $\mathrm{L} / 1$ unit $(8.75 \mathrm{~m})$ is $9,860 \pm 25$ year $\mathrm{BP}$ $(11,252 \pm 11$ cal year BP). This age seems to be distinctly underestimated in comparison with the palynostratigraphic data, as well as with the result obtained for the middle part of the L/1 unit $(8.50 \mathrm{~m})$ $10,570 \pm 30$ year BP $(12,555 \pm 118$ cal year BP $)$. Both values are probably encumbered with a considerable error. According to the palynologic data, both dated layers should be related to the pre-Allerød period. This incompatibility between the dating results (Table 4) and pollen analysis results (Fig. 4) may ensue from the existence of the "radiocarbon plateau" where radiocarbon dates are disturbed by variable and low ${ }^{14} \mathrm{C}$ production in the atmosphere during the time of rapid deglaciation in the Northern Hemisphere (Lowell and Teller 1994). On the other hand, it may be caused by secondary precipitation of calcium carbonate, after permafrost degradation and complete reactivation of groundwater circulation (Fairchild et al. 1994; Bukowska-Jania 2003).

\section{Discussion}

Data from the analyzed core in the center of Lake Bezedna allow us to reconstruct the paleoenvironment of the lake-mire complex. Despite the inconsistent dating results of the chronology of the sediemnts, we try to estimate the regional changes of climate and water conditions through time based mostly on the ostracode fauna and the palynology. The results are presented against the background of regional environmental changes (Fig. 7) and are also compared to the 
Table 4 Results of radiocarbon dating of the Lake Bezedna sediments

\begin{tabular}{|c|c|c|c|c|c|c|}
\hline $\begin{array}{l}\text { Depth } \\
(\mathrm{m})\end{array}$ & Lab. no. & $\mathrm{T}\left({ }^{14} \mathrm{C} \mathrm{BP}\right)$ & $\begin{array}{l}\text { Calibrated age range } \\
\text { at } 68 \%\end{array}$ & $\begin{array}{l}\text { Calibrated age range } \\
\text { at } 94.5 \%\end{array}$ & $\begin{array}{l}\text { Calendar age } \\
\text { cal BC/AD }\end{array}$ & $\begin{array}{l}\text { Calendar age } \\
\text { cal BP }\end{array}$ \\
\hline 3.45 & GdA-2459 & $860 \pm 30$ & 1,159AD $(68.2 \%) 1,219 \mathrm{AD}$ & $\begin{array}{l}1,049 \mathrm{AD}(10.4 \%) 1,085 \mathrm{AD} \\
1,123 \mathrm{AD}(2.8 \%) 1,138 \mathrm{AD} \\
1,151 \mathrm{AD}(82.2 \%) 1,257 \mathrm{AD}\end{array}$ & $1,170 \pm 36$ & $780 \pm 36$ \\
\hline $7.90-7.95$ & GdA-2117 & $7,480 \pm 30$ & $\begin{array}{l}8,363 \mathrm{BP}(50.2 \%) 8,304 \mathrm{BP} \\
8,243 \mathrm{BP}(18.0 \%) 8,215 \mathrm{BP}\end{array}$ & $\begin{array}{l}8,376 \mathrm{BP}(62.1 \%) 8,280 \mathrm{BP} \\
8,266 \mathrm{BP}(33.3 \%) 8,202 \mathrm{BP}\end{array}$ & $6,344 \pm 59$ & $8,294 \pm 59$ \\
\hline $8.10-8.15$ & GdA-2118 & $8,140 \pm 30$ & $\begin{array}{l}9,113 \mathrm{BP}(2.4 \%) 9,109 \mathrm{BP} \\
9,091 \mathrm{BP}(65.8 \%) 9,018 \mathrm{BP}\end{array}$ & $\begin{array}{l}9,240 \mathrm{BP}(1.8 \%) 9,223 \mathrm{BP} \\
9,200 \mathrm{BP}(2.1 \%) 9,179 \mathrm{BP} \\
9,135 \mathrm{BP}(91.6 \%) 9,006 \mathrm{BP}\end{array}$ & $7,123 \pm 38$ & $9,073 \pm 38$ \\
\hline $8.80-8.85$ & GdA-1937 & $8,450 \pm 25$ & $\begin{array}{l}7,570(5.9 \%) 7,560 \mathrm{cal} \mathrm{BC} \\
7,555(62.3 \%) 7,510 \mathrm{cal} \\
\quad \mathrm{BC}\end{array}$ & $\begin{array}{l}7,575(95.4 \%) 7,490 \mathrm{cal} \\
\text { BC }\end{array}$ & $7,538 \pm 18$ & $9,488 \pm 18$ \\
\hline $9.60-9.65$ & GdA-1939 & $10,570 \pm 30$ & $\begin{array}{l}10,640(51.6 \%) \\
\text { BC } \\
10,575 \mathrm{cal} \\
10,515(16.6 \%) \\
\text { BC }\end{array}$ & $\begin{array}{l}10,675(65.3 \%) \\
\text { BC } \\
10,565 \mathrm{cal} \\
\text { BC }\end{array}$ & $10,605 \pm 118$ & $12,555 \pm 118$ \\
\hline $9.85-9.90$ & GdA-1940 & $9,860 \pm 25$ & $\begin{array}{l}9,315(68.2 \%) 9,280 \mathrm{cal} \\
\text { BC }\end{array}$ & $\begin{array}{l}9,360(95.4 \%) 9,265 \mathrm{cal} \\
\mathrm{BC}\end{array}$ & $9,302 \pm 11$ & $11,252 \pm 11$ \\
\hline
\end{tabular}

nearest paleoecologically investigated sites at Słone (Kulesza et al. 2011, 2012; Fig. 1) and Perespilno (Bałaga 2004; Fig. 1) as well as to the Ukrainian lakes in the Volhynia chalkland-Czerepacha and Okunin (Dobrowolski et al. 2001; Dobrowolski 2006; Fig. 1). They are also compared to the Holocene climate variability observed in the northern hemisphere and by climatic-driven lake level changes in mid-Europe (Magny 2004; Fig. 7). The vegetation changes reconstructed from the Lake Słone pollen diagram correspond well to those recorded in the deposits from the Bezedna site. The pollen percentages of the main tree taxa, their maxima and minima, shape of pollen curves, occurrence of indicators of human activity in the area are very similar in both the pollen diagramsBezedna and Lake Słone. This fact additionally supports the palynostratigraphic conclusions and division of the Bezedna pollen diagram. It is especially important because of the mentioned difficulties with radiocarbon dating of the carbonate deposits of the Bezedna lake-mire complex.

\section{Late Glacial/Holocene transition}

Climate changes (recorded in most sites of the Lublin and Volhynia chalklands) occurring at the close of the
Weichselian, and especially those during the Late Glacial/Holocene (LG/H) transition, were very dynamic. Pollen spectra of these oldest deposit layers from Lake Bezedna represent the period of herbaceous vegetation predominance (Older Dryas?), followed by the development of birch-pine boreal forests. In the Younger Dryas they were considerably thinned out and limited by the widespread communities of shrub willows, juniper, and herbs with abundant heliophytes.

At that $\mathrm{LG} / \mathrm{H}$ transition the mean annual air temperature in Central Europe increased by about $12-15{ }^{\circ} \mathrm{C}$ during 4,000 years (Klimanov 1997; Ralska-Jasiewiczowa et al. 1998; Velichko et al. 2002; Błaszkiewicz 2011). During the warmer phases (Bølling and Allerød) the first evidences of carbonate precipitation occurred and typical was the appearance of forest. In the Allerød, the parkland-tundra in the north of Poland passed southwards into Pinus-Betula forest in the warmer uplands (Tyráček 1995). The climate changed especially fast in the eastern, more continental part of Central Europe, in it also in the Volhynia chalkland. The beginning of the Allerød in this region was generally characterised by a longlasting warming with rather low groundwater table. A considerable increase in moisture and acceleration of carbonate sedimentation occurred in the later part of 


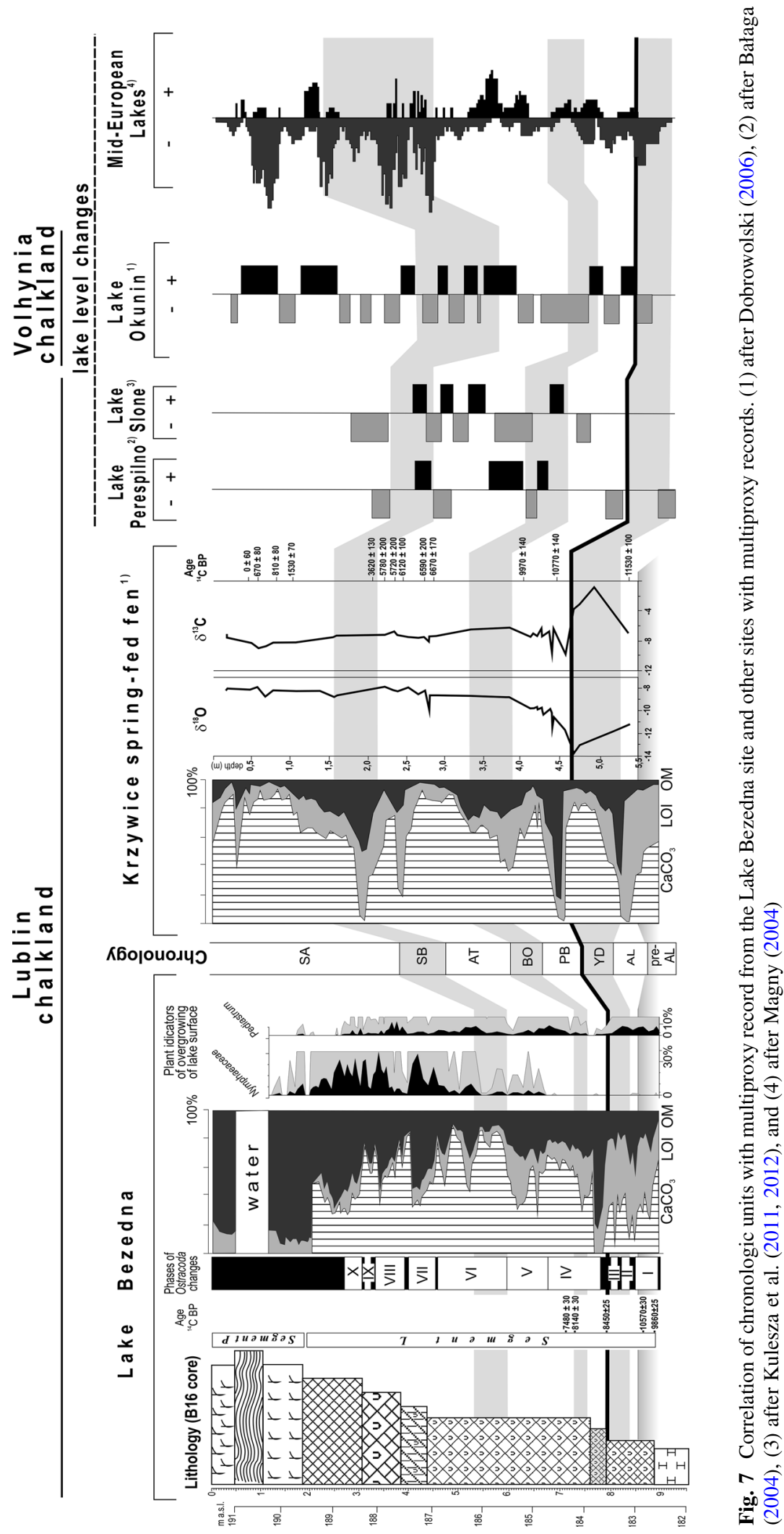


this period. Small, episodic lakes (Czerepacha siteFig. 1) were formed in places (Dobrowolski et al. 2001). In the western part of the Lublin chalkland (Lake Słone, Fig. 1) an increase in the water level was observed, too (Kulesza et al. 2011). Direct data on the water level changes in Lake Bezedna during the Allerød are absent due to the lack of ostracods. However, the appearance of Nymphaea L. in lake vegetation and the disappearance of Menyanthes trifoliata L. can be indirect indicator of the degradation of transitional mire in the lake surroundings and the rise of water level in the lake.

Palynological pattern of Lake Bezedna in Allerød is consistent with that found by Bałaga (2004) in the Allerød sediments of Lake Perespilno although the three pollen zones distinguished in Perespilno are not detectable in Bezedna due to the compactness of the deposits. Allerød is represented in the sediment profile by the L/1 unit. Vegetation of the Bezedna surroundings was represented by birch and pine dominated boreal forests. The appearance of Limnocythere inopinata and Cyclocypris ovum (Jurine 1820) in faunal communities indicates mostly the rise in temperature (Meisch 2000). The subsequent disappearance of ostracods (already in the first part of Allerød) may be related to the maximum warming of this period. This disappearance could have been caused by a change of the lake water trophy. The increase in water temperature in this shallow lake could have resulted in the increasing trophy, which influenced oxygen conditions in the bottom layer of water/hypolimnion. Oxygen depletion in water, resulting in the disappearance of ostracods, is observed in many eutrophic lakes (Scharf 1993). The increase of organic material amount (up to $20 \%$ ) is visible in the results of geochemical analyses.

The occurrence of open plant communities in the Bezedna site, which were associated with very dry continental climate of the Younger Dryas, indicates that pine-birch forests became loose and their area decreased. These changes agree with suggested decrease in annual temperature conditioned mostly by a strong drop of winter temperature (Vaikmäe et al. 1995; Böse 1995) and correspond to the records in other pollen diagrams from this region (Lakes: Perespilno, Słone, Czerepacha), in which the pollen values of herbs increase, especially of different species of Artemisia and Chenopodiaceae. The first part of this period was certainly drier and cooler (the withdrawal of Ulmus, Picea and Nymphaea). This cooling resulted in the intensive changes of ostracod habitat conditions. The beginning of this period, similarly as the pre-Allerød, was characterized by the occurrence of not numerous Candona candida and Fabaeformiscandona protzi. In the second part of Younger Dryas the periods of ostracod disappearance were separated by the development of Fabaeformiscandona protzi and Cypridopsis vidua (O.F. Müller 1776), as well as Cypria opthalmica and Darwinula stevensoni, which indicate the increase in temperature and depth of water (Meisch 2000). These were the first distinct signals of the climate regime transformation during the Late Glacial/Holocene transition.

The boundary between the Late Weischelian and the Holocene is recorded in pollen diagrams by the increase in tree birch values and the decrease in NAP percentages. This boundary is commonly distinguished by means of pollen analysis (Latałowa 2003). In the Bezedna site heliophilous herbs were replaced by birch boreal forests of the Preboreal. Then pine spread, and trees with higher temperature requirements gradually appeared. Humulus lupulus occurred in the spreading elm riverine communities.

\section{Lake origin}

In cold phases of Late Glacial, the environmental conditions did not favor the development of lake basins because the occurrence of permafrost hindered groundwater supply through the carbonate bedrock. Water could have occurred only within taliks, which corresponded to the layer between seasonal and perennial permafrost, as well as to the zones of inherited water circulation within zones of secondary permeability and tectonic faulting (Kudriavcev 1978; Gurney 1998; Wu et al. 2004, 2005). Lauriol and Gray (1990) propose a model of water circulation in a karstified carbonate massif in the modern permafrost zone. They assume a possibility of gravitational vertical flow of meltwater along active tectonic faults-from the ground surface to the underlying permafrost aquifers (the permafrost bottom is the top of the phreatic surface). The following migration routes of groundwater occurred in the European chalklands (Rodet 1991; Dobrowolski 2006): (1) faults and fault zones (mainly of regional rank), (2) extension joints, and (3) interstratal fractures. These conduits were enlarged as a result of mechanical weathering and chemical dissolution. During permafrost aggradation, the existence of earlier formed voids 
favored the development of intrusive ice in the form of sills and veins (Dobrowolski 2006).

Favorable conditions for initiation of the development of shallow lakes took place mostly during the Late Glacial. In Central Europe permafrost probably disappeared temporarily in the Bølling and Allerød time, and developed again during the cold climate oscillations of the Older and Younger Dryas (Rennsen et al. 2000). Permafrost degradation in the Allerød, even under extremely continental climate conditions, was palynologically documented in the central Russia area (Khotinsky and Klimanov 1997). The rate of permafrost degradation was probably rather high. In modern times the thawing rates at the top of permafrost active layer in northern Quebec in Canada are estimated at about $1-13 \mathrm{~cm} \mathrm{year}^{-1}$, and at its bottom at $2.4-5.8 \mathrm{~cm}$ year ${ }^{-1}$ (Buteau et al. 2004). During both warm interphases of the Late Glacial, and especially in the Allerød, the rate of permafrost degradation in European chalklands could have been at least equally fast due to the influence of carbonate substratum (Harasimiuk et al. 1998) and could have resulted in a small but progressive ground subsidence (Dobrowolski 2006). It was associated with the development of small lakes, which were stabilized in the cold phases. Dynamic changes of landscape in periglacial zone are also observed today, for example in Western Siberia, in the form of frequent changes in the number of thermokarst lakes and their area due to permafrost thawing (Karlsson et al. 2012). This is considered to be the response to altering connections between surface water and groundwater. Burn (2002) studied small tundra lakes in the permafrost zone of the western Arctic coast of Canada and observed that relatively warm lake bottoms caused considerable disturbance to the surrounding permafrost. In this area the ground remains frozen year-round, with only a thin layer of $0.5-1.5 \mathrm{~m}$ at the surface thawing during the arctic summer (Dallimore et al. 2000). In the same area the influence of vegetation cover on permafrost distribution can be observed (Camill and Clark 2000). O'Neill and Burn (2012) discuss the controlling role of the vegetation in the development of near-surface ground ice. Shrub-covered wet areas have the highest excess-ice content in the top $50 \mathrm{~cm}$ of permafrost, while grassy, dryer areas are less enriched with ice.

The oldest stage of relatively shallow water bodies in the Lublin and Volhynia chalklands is related to the
pre-Allerød period. Lake Czerepacha, Lake Okunin (Volhynia chalkland), Lake Słone, and Lake Perespilno (Lublin chalkland) originated in the Bøllingabout 12,300 year BP (Goslar et al. 1999; Dobrowolski et al. 2001; Dobrowolski 2006; Kulesza et al. 2011). Pollen analysis indicates that Lake Bezedna developed at the same time. In the light of our findings, Lake Bezedna had cold oligotrophic water, as the only components of ostracode community were Candona candida and Fabaeformiscandona protzi (Meisch 2000). The developing lakes were probably shallow, as indicated by the generally significant occurrence of Pediastrum (Lake Perespilno, Goslar et al. 1999; Fig. 1). Shallow water, rich in calcium carbonate, played a decisive part in the Late Glacial supply of such lakes as Bezedna. Analysis of oxygen stable isotopes in the deposits formed in this period in the Krzywice spring-fed fen (situated in the immediate vicinity of the Bezedna site, Figs. 1,2) indicates the only supply of water is shallow carbonate-rich, lightisotope meltwater from the top parts of weathered karstic bedrock. Cryogenic precipitation of $\mathrm{CaCO}_{3}$, associated with the formation and subsequent degradation of icings (naled ice fields from freezing groundwater flows), was an important lithogenetic process in carbonate deposition at that time (Dobrowolski 2006).

Fast climate change during the $\mathrm{LG} / \mathrm{H}$ transition (units L/2-L/3) considerably influenced the morphogenesis of the Bezedna area. A long-lasting warming resulted in the gradual degradation of permafrost, and so in the general change of groundwater circulation, which led to the re-instatement of vertical groundwater movement (ascending supply was activated). These phenomena occurred in the phases associated with climate oscillations. They were also dependent on lithology, i.e. differences in heat capacity between massive carbonate rocks and Pleistocene unconsolidated mineral deposits (Harasimiuk et al. 1998) and tectonics (faulting of the Upper Cretaceous bedrock). Tectonically weakened zones in weathered karst, were reactivated by glacio-isostatic movements and permafrost degradation, which resulted in the re-instatement of groundwater vertical circulation. Ascending water flowed onto the ground surface in spring zones that simultaneously subsided (in extreme cases collapsed) as a result of carbonate dissolution. Ascending spring waters could have disappeared soon after the complete degradation of permafrost or it could have lasted for a 
long time after permafrost degradation. In the latter case the residual clays of a weathered karstic landscape, glacio-tectonic breccias and/or impermeable glaciogenic deposits (tills and glacifluvial silts, Fig. 2) could have been the confining layer allowing spring development (Dobrowolski 2006).

The complete and final degradation of permafrost in the Lublin chalkland probably occurred only in the Preboreal (Harasimiuk et al. 1998; Dobrowolski 2006). The beginning of the Holocene was proposed as the latest time of permafrost occurrence in the central part of the North European Plain (Böse 1995), but the rate of its decline was high, completely melting away during only 1,000-1,500 years (Gerasimov and Velichko 1982; Błaszkiewicz 2011). Such rate of permafrost disappearance resulted in catastrophic changes (Velichko 1973) and was a widespread phenomenon in the northern hemisphere. The research on ice-rich permafrost sequences in northern Siberia indicates that extensive thermo-erosion and thermodenudation processes with the formation of large thermokarst lakes, taliks, and thermo-erosional valley systems occurred between 12 and 7 ky BP (Schirrmeister et al. 2002). In the Bezedna study area, the complete transformation of relief consisted of largescale ground subsidence and development of closed depressions, which were circular or oval in shape, of different sizes (from $<1$ to $>100$ ha and depth from $2 \mathrm{~m}$ to over $50 \mathrm{~m}$ ). Most of these forms filled up with water and were functioning as lakes in the Holocene stage of their development (Bałaga 1982, 1991; Zernitskaya 1997; Dobrowolski et al. 2001; Dobrowolski 2006). According to the commonly accepted opinion, the Late Glacial melting of permafrost was the most effective morphogenetical process occurring in the ice-sheet foreland during the whole Weichselian (Gerasimov and Velichko 1982; Ritter et al. 1995). In the central Yakutia (NE Russia) contemporaneously the depth of thaw below small water bodies can reach $8-10 \mathrm{~m}$ within 50 years and $20 \mathrm{~m}$ within 300 years in spite of the very low annual temperature about $-10{ }^{\circ} \mathrm{C}$ (Brouchkov et al. 2005).

The results of investigations carried out in the Bezedna site seem to support the interpretation (Dobrowolski 2006) that the degradation of intrusive ice filling interstratal fractures in the karstic bedrock in the warm interphases of the Late Weichselian and/or Preboreal caused the discharge of considerable hydraulic pressures and resulted in: (1) efficient ascending supply of groundwater, (2) intensive weathering and dissolution of bedrock, and (3) progressive ground subsidence/collapse. Similar cases are reported from the areas affected by modern permafrost (Tolstichin and Chimichev 1981; Gurney 1998).

As the activation of deep circulation of groundwater near the Bezedna site was preceded by the phase (or phases) of weathering and dissolution of karst in phreatic conditions, the outflow of carbonate-rich groundwater produced carbonate deposition on the bottoms of the newly-formed lakes (Dobrowolski 2006). Carbonate-rich groundwater can produce carbonate sediments in lakes (Gierlowski-Kordesch 2010; Renaut and Jones 2010).

\section{Holocene}

In the Preboreal period, forests dominated by birch and pine were gradually replaced by pine-birch forests with expanding hazel. Environmental conditions were reflected by changes in the lithology of the lake sediments (L/2 unit). Oak followed by alder appeared in forests in the younger part of the Preboreal. With the forest in the lake surroundings, the next period of ostracode disappearance was recorded in the lake (transition from $\mathrm{L} / 2$ to $\mathrm{L} / 3$ unit). It can be related to the change of oxygen conditions, similar to that of the Allerød period, which resulted from the intensive decomposition of organic matter. At that time its content in the deposits was over $80 \%$. In the next stages of the Preboreal period, the continuous tendency of temperature increase is mostly evidenced by the appearance of Metacypris cordata (Absolon 1973). Besides Metacypris cordata, Cyclocypris laevis, Limnocythere inopinata, and Darwinula stevensoni occurred. A considerable and stable change of climate conditions was also indicated by the increased number of ostracode species and specimens. The water depth considerably increased only in the last part of the period as indicated by the appearance of Darwinula stevensoni and Limnocythere inopinata, and the higher number of Fabaeformiscandona protzi specimens (Meisch 2000). The generally low water level phase in the Preboreal is well documented in numerous lake profiles across Europe (Gaillard 1984; Digerfeldt 1988; Magny and Ruffaldi 1995). It seems that a considerable increase of the Lake Bezedna depth in the second part of the Preboreal resulted from ground subsidence due to the long-lasting warming, which 
caused a complete decline of permafrost (bottom part of the $L / 3$ unit).

In the Boreal period (unit $L / 3$ ), the increase in temperature caused forest transformation. Dynamic expansion of hazel, followed by oak, elm, and lime, was one of the characteristic features of these changes. The proportion of pine decreased gradually indicating that it was displaced on the poorest habitats. The tendency of temperature rise in the Boreal period was recorded in the nature of ostracode communities. However, the temperature conditions were more stable as indicated by the increased species diversity and number of specimens. In the Volhynia chalkland, the cooling and moisture decrease in the Boreal $(9,300-8,400$ year BP) were recorded by the lowering of the groundwater table and the increase in redox indices; the lacustrine sedimentation rate distinctly fell (about $0.11 \mathrm{~cm} \mathrm{year}^{-1}$ ) (Dobrowolski et al. 2001).

The palynologically determined beginning of the Atlantic period (middle part of the L/3 unit) corresponds to the results of radiocarbon dating 9,073 \pm 38 cal year BP $(7,123 \pm 38$ cal year BC), which is consistent with the chronologic scheme developed by Mangerud et al. (1974) (Walanus and Nalepka 2010). The Atlantic period was the time when climax deciduous forests with oak, elm, lime and ash developed. Results of pollen analysis indicate that multi-species deciduous forests remained stable for a long time. It was also characterized by the greatest species diversity of ostracodes and the highest number of their specimens (middle part of the L/3 unit). A slow increase in mean air temperature and precipitation occurring in the Atlantic period $(8,400-5,000$ year BP) was connected with the rise of the groundwater table in the Volhynia chalkland (Okunin Lake). This long-lasting rise in air temperature and moisture was interrupted only in the middle Atlantic period by one short episode of cooling and lowering of the groundwater table that was radiocarbon dated at 6,300-6,600 year BP (Kalis et al. 2003). This episode is also recorded in the deposits from the Bezedna site by the disappearance of Darwinula stevensoni and Fabaeformiscandona protzi in the ostracode communities of the middle part of the Atlantic period. A similar episode was also found in other sites of the Lublin-Volhynia chalklands (Dobrowolski et al. 2001; Kulesza et al. 2012).

The boundary between the Atlantic period and Subboreal period (upper part of the L/3 unit) is marked by the decrease in elm pollen. This phenomenon occurred almost synchronously in the whole of Europe and was radiocarbon dated at 5,100-5,000 year BP (Latałowa 2003). At that time dry-ground forest communities with hornbeam began to develop, and beech probably occurred in patches. The increase of oak and hazel proportions was probably a result of better light conditions due to degeneration of elm riverine forests and formation of dry-ground forests, which were similar to the modern communities of Tilio-Carpinetum with hornbeam, oak and hazel. In pollen spectra of that time, the first pollen grains of Plantago lanceolata L. appear and the values of sorrel increase indicating pasturage of livestock near the site. These indicators probably represent Bronze Age settlement. Nature of the ostracode communities points toward a general temperature decrease. This is mostly indicated by the decreased number of Metacypris cordata specimens, and the disappearance of Notodromas monacha and Cypridopsis vidua. The Subboreal period in the Volhynia chalkland area was characterized by considerable fluctuations in temperature and moisture, evidenced by a great variability of biologic proxies (pollen and ostracodes).

The changes in eastern Poland coincided with general trends of climate conditions widespread over the Northern Hemisphere, the 6,000-5,000 and 3,500-2,500 cal year BP intervals feature the North Atlantic ice rafting events (Bond et al. 1997), alpine glacier advances (Denton and Karlén 1973), and strengthened westerlies over the North Atlantic and Siberia (Meeker and Mayewski 2002). In Scandinavia, the tree line limit rose in elevation and mountain glaciers advanced in the first interval $(6,000-5,000$ cal year BP), but the situation reversed in the second interval $(3,500-2,500 \mathrm{cal}$ year BP). Cooling over the northeast Mediterranean was related to winter-time continental/polar air outbreaks (Mayewski et al. 2004).

The thickest part of the Bezedna lacustrine deposits was formed in the Subatlantic period (units L/4-L/6 and $\mathrm{P} / 7-\mathrm{P} / 8$ ), when the distinct expansion of Carpinus betulus and Fagus sylvatica occurred, and several phases of intensified human activity were recorded. Information obtained from the archaeological survey of Poland also indicates that the Chełm region $(2.5 \mathrm{~km}$ from the Bezedna site) was settled as early as 5,500 years BC. Several very high maxima in Нитиlus/Cannabis pollen values evidence hemp wetting in Lake Bezedna during several settlement episodes. This considerable thickness of deposits was probably caused 
by a high rate of accumulation, resulting from the eutrophication of the lake, mostly due to anthropogenic activities and occupation of the lake surface by abundant Nymphaeaeceae. The lake gradually became shallow and the rush belt covered larger and larger areas as indicated by the high pollen values of Typha latifolia L. at the end of the Subatlantic period and a transitional mire with Menyanthes trifoliata developed in the lake surroundings. According to the ostracode species composition, the Subatlantic period began with considerable oscillations of generally decreasing lake depth. The second part of this period was characterized by quite stable temperature and water depth but with the decreasing tendency in both these variables towards the end of the period. The Subatlantic in the Volhynia chalkland $(<2.8 \mathrm{ka} \mathrm{BP})$ was characterized by rather stable temperature conditions and small fluctuations of moisture. Mean air temperature was gradually increasing after a slight cooling at the turn of the Subboreal and Subatlantic periods. The groundwater table also rose. Summary of chronostratigraphic zonation of Bezedna lake-mire deposits is presented in Table 5.

\section{Conclusions}

Results of multi-proxy studies of the lake-mire deposits from the Bezedna site evidenced local environment changes (moisture-temperature and biotic) in the last about $12 \mathrm{ka}$ years. Correlation of paleobotanical and ostracode paleofaunal data with the results of paleoenvironmental investigations carried out in the adjacent regions (Volhynia chalkland) allowed us to find unique elements in the sequence of climate changes of the Late Glacial/Holocene transition in eastern Poland based on the influence of continental climate and the sedimentary and paleohydrologic processes unique to carbonate bedrock (Lublin chalklands) of Upper Cretaceous age. The climate system during the Late Glacial/Holocene transition and the associated response of carbonate substratum that was deeply frozen in the preceding Weichselian was of key importance to the development of paleohydrologic changes affecting sedimentation and faunal and floral change. Degradation of intrusive ice, being the primary infilling of interstratal fractures within the karstic bedrock, resulted in the discharge of considerable hydraulic pressures by the re-activation of groundwater circulation. In addition,
Table 5 Relation of the lithologic units in the Lake Bezedna deposits to chronostratigraphic zonation

\begin{tabular}{|c|c|c|}
\hline $\begin{array}{l}\text { Height } \\
\text { (m a.s.1.) }\end{array}$ & Segment/unit & $\begin{array}{l}\text { Chronostratigraphic } \\
\text { zonation }\end{array}$ \\
\hline $191.45-191.05$ & $\mathrm{P} / 8$ & Subatlantic \\
\hline $191.05-190.15$ & Water & \\
\hline $190.15-189.20$ & $\mathrm{P} / 7$ & \\
\hline $189.20-187.85$ & $\mathrm{~L} / 6$ & \\
\hline $187.85-187.05$ & $\mathrm{~L} / 5$ & \\
\hline $187.05-186.45$ & $\mathrm{~L} / 4$ & \\
\hline \multirow[t]{5}{*}{$186.45-182.90$} & $\mathrm{~L} / 3$ & Subaltantic (older part) \\
\hline & & Subboreal \\
\hline & & Atlantic \\
\hline & & Boreal \\
\hline & & Preboreal (younger part) \\
\hline \multirow[t]{2}{*}{$182.90-182.50$} & $\mathrm{~L} / 2$ & Preboreal (older part) \\
\hline & & $\begin{array}{l}\text { Younger Dryas/Preboreal } \\
\text { transition }\end{array}$ \\
\hline \multirow[t]{3}{*}{$182.50-181.55$} & $\mathrm{~L} / 1$ & Younger Dryas \\
\hline & & Allerød \\
\hline & & Pre-Allerød \\
\hline Below 181.55 & Bedrock & Upper Cretaceous \\
\hline
\end{tabular}

the re-instatement of an ascending supply of groundwater induced intensive weathering and dissolution of carbonate bedrock and progressive ground subsidence and sinkhole formation. These events are recorded in the lacustrine (limnetic, L) sequence, which consists of sapropelic carbonate mud (deposited biochemically from water rich in calcium carbonate) interbedded with massive dark brown sapropel (deposited during the episodes of progressive deepening of the lake). The indirect biotic record of these events was the periodic disappearance of ostracodes during the Late Glacial stage of lake evolution. It was caused by the sudden change of habitat conditions, and corresponded with the deposition of massive dark brown sapropel.

Acknowledgments We wish to thank two anonymous reviewers and Associate Editor Elizabeth GierlowskiKordesch for their helpful comments, which greatly improved our manuscript. Special thanks to Dr Stanisław Chmiel from the Department of Hydrology (Faculty of Earth Sciences and Spatial Management MCSU in Lublin) for the hydrochemical analyses. This study was financed partially from the funds of the Polish Ministry of Science and Higher Education No. NN306 066534 (2008-2011) Grant, No. NN527 198138 (2010-2013) Grant, and from the funds of the Faculty of Earth Sciences and Spatial Management MCSU in Lublin. 
Open Access This article is distributed under the terms of the Creative Commons Attribution License which permits any use, distribution, and reproduction in any medium, provided the original author(s) and the source are credited.

\section{References}

Absolon A (1973) Ostracoden aud einigen Prolenspa atund postglazialer Karbonatablagerungen in Mitteleuropa. Mitteilungen der Bayerischen Staatssammlung fur Palaaontologie und historische Geologie 1347:1-94

Bałaga K (1982) Vegetational history of Lake Łukcze Environment (Lublin Polesie, E Poland) during the Late-Glacial on Holocene. Acta Palaeobot 22(1):7-22

Bałaga K (1991) The development of Lake Łukcze and changes in the plant cover the South-Western part of the ŁęcznaWłodawa Lake District in the last 13000 years. Acta Palaeobot 30(1/2):77-146

Bałaga K (2004) Changes of vegetation in Lake Perespilno environs (Lublin Polesie) in the Late Glacial and Holocene. Acta Palaeobot 44(2):147-166

Barber K, Zolitschka B, Tarasov P, Lotter AF (2004) Atlantic to Urals - the Holocene climatic record of mid-latitude Europe. In: Battarbee RW et al (eds) Past Climate Variability through Europe and Africa. Kluwer Academic Publishers, Dordrecht, pp 417-442

Belis CA, Finsinger W, Ammann B (2008) The late glacialHolocene transition as inferred from ostracod and pollen records in the Lago Piccolo di Avigliana (Northern Italy) Palaeogeogr. Palaeoclimatol Palaeoecol 264:306-317

Berglund BE, Ralska-Jasiewiczowa M (1986) Pollen analysis and pollen diagrams. In: Berglund BE, Ralska-Jasiewiczowa M (eds) Handbook of Holocene Palaeoecology and Palaeohydrology. Wiley, Chichester

Björck S, Kromer B, Johnsen S, Bennike O, Hammarlund D, Lemdahl G, Possnert G, Rasmussen TL, Wohlfarth B, Hammer CU, Spurk M (1996) Synchronised terrestrialatmospheric deglacial records around the North Atlantic. Science 274:1155-1160

Błaszkiewicz M (2011) Timing of the final disappearance of permafrost in the central European Lowland, as reconstructed from the evolution of lakes in N Poland. Geol Q 55(4):361-374

Bond G, Showers W, Cheseby M, Lotti RP, de Menocal AP, Priore P, Cullen H, Hajdas I, Bonani G (1997) A pervasive millennial-scale cycle in North Atlantic Holocene and Glacial climates. Science 278:1257-1266

Böse M (1995) Problems of dead ice and ground ice in the central part of the North European Plain. Quat Int 28:123-125

Bronk Ramsey C (2001) Development of the radiocarbon calibration program OxCal. Radiocarbon 43(2A):355-363

Brouchkov A, Fukuda M, Iwahana G, Kobayashi Y, Konstantinov P (2005) Thermal conductivity of soils in the active layer of eastern Siberia. Permafrost Periglac Process 16:217-222

Bukowska-Jania E (2003) Rola systemu lodowcowego w obiegu węglanu wapnia w środowisku przyrodniczym. Silesian University Press, Katowice
Burn CR (2002) Tundra lakes and permafrost, Richards Island, western Arctic coast, Canada. Can J Earth Sci 39:12811298

Buteau S, Fortier R, Delisle G, Allard M (2004) Numerical simulation of the impacts of climate warming on a permafrost mound. Permafrost Periglac Process 15(1):41-57

Camill P, Clark JS (2000) Long-term perspectives on lagged ecosystem responses to climate change: permafrost in boreal peatlands and the grassland/woodland boundary. Ecosystems 3:534-544

Coope GR, Lemdahl G (1995) Regional differences in the Late Glacial climate of northern Europe based on coleopteran analysis. J Quat Sci 10:391-395

Dallimore A, Schröder-Adams CJ, Dallimore SR (2000) Holocene environmental history of thermokarst lakes on Richards Island, Northwest Territories, Canada: theocamoebians as paleolimnological indicators. J Paleolimnol 23(3):261-283

Denton GH, Karlén W (1973) Holocene climatic variationstheir pattern and possible cause. Quat Res 3:155-205

Diepenbroek M, Grobe H, Sieger R (2001) PanPlot, http://www. pangaea.de/Software/PanPlot, pp 1-25

Digerfeldt G (1988) Reconstruction and regional correlation of Holocene lake-level fluctuations in Lake Bysjön, South Sweden. Boreas 17:165-182

Dobrowolski R (1995) Drobne struktury tektoniczne w skałach górnokredowych wschodniej części Wyżyny Lubelskiej a dyslokacje podłoża platformy wschodnioeuropejskiej w kenozoiku. Ann Soc Geolog Polon 65(1-4):79-91

Dobrowolski R (2006) Glacjalna i peryglacjalna transformacja rzeźby krasowej północnego przedpola wyżyn lubelskowołyńskich (Polska SE, Ukraina NW). Wydawnictwo UMCS, Lublin

Dobrowolski R, Bałaga K, Bogucki A, Fedorowicz S, Melke J, Pazdur A, Zubowič S (2001) Chronostratigraphy of the Okunin and Czerepacha lake-mire geosystems (Volhynia Polesiye, NW Ukraine) during the Late Glacial and Holocene. Geochronometria 20:107-115

Fairchild IJ, Bradby L, Spiro B (1994) Reactive carbonate in glacial systems: a preliminary synthesis of its creation, dissolution and reincarnation. In: Deynoux M, Miller JG, Domack E, Eyles N, Fairchild IJ, Young GM (eds) Earth's Glacial Record. Cambridge University Press, Cambridge

Feurdean A, Mosbrugger V, Onac B, Polyak V, Veres D (2007) Younger Dryas to mid-Holocene environmental history of the lowlands of NW Transylvania, Romania. Quat Res 68:364-378

Gaillard MJ (1984) A palaeohydrological study of Krageholmssjöm (Scania, South Sweden). Regional vegetation, history and water-level changes. Lundqua Rep 25:1-40

Gerasimov IP, Velichko AA (1982) Paleogeografija Evropy za poslednie sto tysiac let (Palaeogeography of Europe during the last hundred thousand years). Izdatelstvo Nauka, Moskva

Gierlowski-Kordesch EH (2010) Lake carbonates. In: AlonsoZarza AM, Tanner LH (eds) Carbonates in continental settings: facies, environments, and processes. Elsevier, Amsterdam

Goslar T, Bałaga K, Arnold M, Tisnerat N, Starnawska E, Kuźniarski M, Chróst L, Walanus A, Więckowski K (1999) 
Climate-related variations in the composition of the Late Glacial and early Holocene sediments of Lake Perespilno (eastern Poland). Quat Sci Rev 18:899-911

Griffiths HI (1995) European quaternary freshwater Ostracoda: a biostratigraphic and palaeobiogeographic primer. Geol Palaeontol Scopol 34:1-168

Griffiths HI, Evans JG (1995) The Late-Glacial and early Holocene colonisation of the British Isles by freschwater Ostracoda. In: Ř́ha J (ed) Ostracoda and biostratigraphy. Proceedingsof the twelfth international symposium on Ostracoda, Praque, Czech Republic, A.A. Balkema Publishers, Rotterdam

Gurney SD (1998) Aspects of the genesis and geomorphology of pingos: perennial permafrost mounds. Prog Phys Geogr 22:307-324

Harasimiuk M, Michalczyk Z, Turczyński M (1998) Jeziora Łęczyńsko-Włodawskie. Monografia Przyrodnicza, Biblioteka Monitoringu Środowiska, Lublin

Harasimiuk M, Superson J, Szwajgier W (2002) The influence of autogenic and allogenic factors on the evolution of Lake Pniówno (the Chełm Hills, eastern Poland). Limnol Rev 2:143-154

Harasimiuk M, Jezierski W, Rzechowski J (2006a) Objaśnienia do Szczegółowej Mapy Geologicznej Polski w skali 1:50000, ark Chełm (789). Ministerstwo Środowiska. Państwowy Instytut Geologiczny, Warszawa

Harasimiuk M, Król T, Rzechowski J (2006b) Objaśnienia do Szczegółowej Mapy Geologicznej Polski w skali 1:50000, ark Kamień (790). Ministerstwo Środowiska. Państwowy Instytut Geologiczny-Państwowy Instytut Badawczy, Warszawa

Heiri O, Lotter AF, Hausmann S, Kienast F (2003) A chironomid- based Holocene summer air temperature reconstruction from the Swiss Alps. Holocene 13:477-484

Hiller D (1972) Untersuchumgen zur Biologie und zur Ökologie limnischer Ostracoden aus der Umgebung von Hamburg. Arch Hydrobiol Suppl Band 40:400-497

Hoek WZ, Bohncke SJP (2002) Climatic and environmental events over the Last Termination, as recorded in The Netherlands; a review. Neth J Geosci 81:123-137

Huijzer AS, Isarin RFB (1997) The reconstruction of past climates using multi-proxy evidence; an example of the Weichselian Pleniglacial in northwestern and central Europe. Quaternary Sci Rev 16:513-533

Kalis AJ, Merkt J, Wunderlich J (2003) Environmental changes during the Holocene climatic optimum in central Europehuman impact and natural causes. Quat Sci Rev 22:33-79

Karlsson JM, Lyon SW, Destouni G (2012) Thermokarst lake, hydrological flow and water balance indicators of permafrost change in Western Siberia. J Hydrol 464-465:459-466

Khotinsky NA, Klimanov VA (1997) Alleröd, Younger Dryas and early Holocene Palaeo-environmental stratigraphy. Quatern Int 41(42):67-70

Klimanov VA (1997) Late Glacial climate in northern Eurasia: the last climatic cycle. Quat Int 41(42):141-152

Koç N, Jansen E, Haflidason H (1993) Paleoceanographic reconstructions of surface ocean conditions in the Greenland, Iceland and Norwegian seas through the last $14 \mathrm{ka}$ based on diatoms. Quat Sci Rev 12:115-140

Kofler W, Krapf V, Oberhuber W, Bortenschlager S (2005) Vegetation responses to the $8200 \mathrm{cal}$. BP cold event and to long-term climatic changes in the Eastern Alps: possible influence of solar activity and North Atlantic freshwater pulses. Holocene 15:779-788

Kokfelt U, Reuss N, Struyf E, Sonesson M, Rundgren M, Skog G, Rosen P, Hammarlund D (2010) Wetland development, permafrost history and nutrient cycling inferred from late Holocene peat and lake sediment records in subarctic Sweden. J Paleolimnol 44:327-342

Kudriavcev VA (1978) Obshchee merzlotovedenie (geokriologija). Izdatelstvo Moskovskogo Universiteta, Moskva

Kulesza P, Suchora M, Pidek IA, Alexandrowicz WP (2011) Chronology and directions of Late Glacial paleoenvironmental changes: a multi-proxy study on sediments of Lake Słone (SE Poland). Quat Int 238:89-106

Kulesza P, Suchora M, Pidek IA, Dobrowolski R, Alexandrowicz WP (2012) The Holocene palaeoenvironmental changes reflected in the multi-proxy studies of Lake Słone sediments (SE Poland). Palaeogeogr Palaeoclimatol Palaeoecol 363-364:79-98

Latałowa M (2003) Holocene. In: Dybova-Jachowicz S, Sadowska A (eds) Palinologia. IB PAN, Kraków

Lauriol B, Gray JT (1990) Drainage karstique en Lilieu de pergelisol: le cas de i'ile d'Akpatok, T.N.O. Canada. Permafrost Periglac Process 1:129-144

Litt T, Stebich M (1999) Bio- and chronostratigraphy of the Lateglacial in the Eifel region, Germany. Quatern Int 61:5-16

Litt T, Brauer A, Goslar T, Merkt J, Balaga K, Müller H, RalskaJasiewiczowa M, Stebich M, Negendank JFW (2001) Correlation and synchronisation of Lateglacial continental sequences in northern central Europe based on annually laminated lacustrine sediments. Quat Sci Rev 20:1233-1249

Litt T, Schmincke H-U, Kromer B (2003) Environmental responses to climatic and volcanic events in central Europe during the Weichselian Lateglacial. Quat Sci Rev 22:7-32

Lowell TV, Teller JT (1994) Radiocarbon vs. calendar ages of major lateglacial hydrological events in North America. Quat Sci Rev 13:801-803

Mackay JR (1978) Contemporary pingos: a discussion. Biul Peryglac 27:133-154

Mackay JR (1988) Catastrophic lake drainage, Tuktoyaktuk Peninsula area, District of Mackenzie. Geological Survey Canada Paper 88-1D, pp 83-90

Magny M (2004) Holocene climate variability as reflected by mid-European lake-level fluctuations and its probable impact on prehistoric human settlements. Quatern Int 113:65-79

Magny M, Ruffaldi P (1995) Younger Dryas and early Holocene lake-level fluctuations in the Jura Mountains, France. Boreas 24:155-172

Magny M, Bégeot C, Guiot J, Peyron O (2003) Contrasting patterns of hydrological changes in Europe in response to Holocene climate cooling phases. Quaternary Sci Rev 22:1589-1596

Mangerud J, Andersen ST, Berglund BE, Donner J (1974) Quaternary stratigraphy of Norden, a proposal for terminology and classification. Boreas 3:109-126

Maruszczak H (1966) Zjawiska krasowe w skałach górnokredowych międzyrzecza Wisły i Bugu (Typ krasu kredy piszaccej). Przegląd Geograficzny 38:339-370

Mayewski PA, Rohling EE, Stager JC, Karlén W, Maasch KA, Meeker LD, Meyerson EA, Gasse F, van Kreveld S, 
Holmgren K, Lee-Thorp J, Rosqvist G, Rack F, Staubwasser M, Schneider RR, Steig EJ (2004) Holocene climate variability. Quat Res 62:243-255

Meeker LD, Mayewski PA (2002) A 1400-year high-resolution record of atmospheric circulation over the North Atlantic and Asia. Holocene 12:257-266

Meisch C (2000) Freshwater Ostracoda of western and central Europe. In: Schwoerbel J, Zwick P (eds) Suesswasserfauna von Mitteleuropa 8/3. Spektrum Akademischer Verlag, Heidelberg

Miall AD (1978) Lithofacies types and vertical profile models in braided river deposits: a summary. In: Miall AD (ed) Fluvial sedimentology. Canadian Society for Petroleum Geology Memoir 5:597-604

Müller F (1959) Beobachtungen über Pingos. Detailuntersuchungen in Ostgrönland und in der kanadischen Arktis. Meddelelser om Grønland 153:1-127

Nakagawa T, Kitagawa H, Yasuda Y, Tarasov PE, Nishida K, Gotanda K, Sawai Y, Yangtze River Civilization Program Members (2003) Asynchronous climate changes in the North Atlantic and Japan during the last Termination. Science 299:688-691

Nalepka D, Walanus A (2003) Data processing in pollen analysis. Acta Palaeobot 43:125-134

O'Neill HB, Burn CR (2012) Physical and temporal factors controlling the development of near-surface ground ice at Illisarvik, western Arctic coast, Canada. Can J Earth Sci 49:1096-1110

Ralska-Jasiewiczowa M, Goslar T, Madeyska T, Starkel L (eds) (1998) Lake Gościąż, central Poland. A monographic study. Part 1. W. Szafer Institute of Botany, Polish Academy of Sciences, Kraków

Reimer PJ, Baillie MGL, Bard E, Bayliss A, Beck JW, Bertrand C, Blackwell PG, Buck CE, Burr G, Cutler KB, Damon PE, Edwards RL, Fairbanks RG, Friedrich M, Guilderson TP, Hughen KA, Kromer B, McCormac FG, Manning S, Bronk Ramsey C, Reimer RW, Remmele S, Southon JR, Stuiver M, Talamo S, Taylor FW, van der Plicht J, Weyhenmeyer CE (2004) IntCal04 terrestrial radiocarbon age calibration, 0-26 cal kyr BP. Radiocarbon 46:1029-1058

Renaut RW, Jones B (2010) Calcareous spring deposits in continental settings. In: Alonso-Zarza AM, Tanner LH (eds) Carbonates in continental settings: facies, environments, and processes. Elsevier, Amsterdam

Rennsen H, Isarin RFB, Vandenberghe J, Lautenschlager M, Schlese U (2000) Permafrost as a critical factor in palaeoclimate modelling: the Younger Dryas case in Europe. Earth Planet Sci Lett 176:1-5

Ritter DF, Kochel RC, Miller JR (1995) Process geomorphology. McGraw-Hill, New York

Rodet J (1991) Les karsts de la craie - étude comparative. Thèse du Doctorat d'Etat. Université de Paris IV-Sorbonne

Scharf BW (1993) Ostracoda (Crustacea) and Trichoptera (Insecta) from Late and post-Glacial sediments of some European maar lakes. In: Negendank JFW, Zolitschka B (eds) Paleolimnology of European Maar Lakes Lecture Notes in Earth Sciences 49. Springer, Berlin, pp 435-439

Schirrmeister L, Siegert C, Kuznetsova T, Kuzmina S, Andreev AA, Kienast F, Meyer H, Bobrov A (2002) Paleoenvironmental and paleoclimatic records from permafrost deposits in the Arctic region of northern Siberia. Quat Int 89:97-118
Schnurrenberger D, Russell J, Kelts K (2003) Classification of lacustrine sediments based on sedimentary components. J Paleolimnol 29:141-154

Seppä H, Birks HJB, Giesecke T, Hammarlund D, Alenius T, Antonsson K, Bjune AE, Heikkilä M, MacDonald GM, Ojala AEK, Telford RJ, Veski S (2007) Spatial structure of the 8200 cal yr BP event in northern Europe. Climate Past 3:225-236

Tolstichin ON, Chimichev LG (1981) Zakonomiernosti raspostranienija i razwitija nalednych processov. In: Alekseev VR (ed) Naledi Sibiri i Daľnego Vostoka. Nauka, Novosibirsk

Troels-Smith J (1955) Karakterisering af lose jordater (Characterization of unconsolidated sediments). Denmarks Geologiske Undersogelse, Series IV/3, 10: 1-73

Tyráček J (1995) Depositional changes in non-glaciated regions of central Europe. Quatern Int 28:77-81

Vaikmäe R, Böse M, Michel FA, Moormann BJ (1995) Changes in permafrost conditions. Quat Int 28:113-118

Valero-Garces B, Morellón M, Moreno A, Corella JP, MartínPuertas C, Barreiro F, Pérez A, Giralt S, Mata-Campo MP (2014) Lacustrine carbonates of Iberian karst lakes: sources, processes, and depositional environments. Sed Geol 299:1-29

Velichko AA (1973) Osnovnye cherty kriogeneza ravninnych territorij Evropy v verchnem plejstocene. Mat. mezhdunarod. konf. po merzlotoved, Jakutsk

Velichko AA, Catto N, Drenova AN, Klimanov YA, Kremenetski KY, Nechaev YP (2002) Climate changes in East Europe and Siberia at the Late Glacial-Holocene transition. Quat Int 91:75-99

Walanus A, Nalepka D (2010) Calibration of Mangerud's boundaries. Radiocarbon 52(4):1639-1644

Washburn AL (1979) Geocryology: a survey of periglacial processes and environments. Edward Arnold, London

Wilgat T (1954) Jeziora Łęczyńsko-Włodawskie. Annales UMCS sect. B 8:37-122

Wilkinson IP, Bubikyan SA, Gulakyan SZ (2005) The impact of late Holocene environmental change on lacustrine Ostracoda in Armenia. Palaeogeogr Palaeoclimatol Palaeoecol 225:187-202

Wohlfarth B, Blaauw M, Davies SM, Andersson M, Wastegård S, Hormes A, Posnert G (2006) Constraining the age of Late Glacial and early Holocene pollen zones and tephra horizons in southern Sweden with Bayesian probability methods. J Quat Sci 21:321-334

Wojtanowicz J (1994) O termokrasowej genezie jezior łęczyńsko-włodawskich. Annales Universitatis Mariae Curie Sklodowska, sect B 49:1-18

Wu Z, Barosh PJ, Hu D, Wu Z, Zhao X, Peisheng Y, Jiang W (2004) Hazards posed by active major faults along the Golmud-Lhasa railway router, Tibetan Plateau, China. Eng Geol 74:163-182

Wu Z, Barosh PJ, Hu D, Wu Z, Zhao X, Peisheng Y, Qisheng L, Zhou C (2005) Migrating pingos in the permafrost region of the Tibetan Plateau, China, and their hazard along the Golmud-Lhasa railway. Eng Geol 79:267-287

Zernitskaya VP (1997) The evolution of lakes in the Poles'ye in the Late Glacial and Holocene. Quatern Int 41(42):153-160

Zwoliński Z, Rachlewicz G, Mazurek M, Paluszkiewicz R (2007) The geoecological model for small tundra lakes, Spitsbergen. Landform Anal 5:113-118 